\title{
Nutritional and Therapeutic Potential of Allium Vegetables
}

\author{
Ravi Kant Upadhyay
}

\author{
Department of Zoology, D D U Gorakhpur University, Gorakhpur 273009, U.P., India
}

\begin{abstract}
Allium vegetables are highly nutritional, its dietary use improves digestion and mental health and lower down cholesterol level. Use of onions, garlic, scallions, chives and leeks show therapeutic efficacy against cardiovascular disease, hyperglycemia, and stomach cancer, Onions contain allylsulfides and flavonoids particularly quercetin that is an important anti-oxidative and reduces hepatocytes apoptosis in streptozotocin-induced diabetic rat. Steroid saponins and sapogenins present in garlic bulbs are used to prepare soft soaps. $\beta$-chlorogenin is a characteristic steroid sapogenin from garlic that is used for skin ointment and as a shiner. Both garlic paste and soft garlic preparations are used for flavoring the food items. Garlic products that contain the most safe, effective, stable, and odorless components are the most valuable as dietary supplements. Garlic also contains non sulfur compounds such as steroid saponins. Alliums showed antimicrobial, antithrombotic, antitumor, anti-hyperlipidaemic, antiarthritic, anti-hyperglycemic anticarcinogenic potential. Allium vegetables contain organosulfur compounds, including DATS, diallyl disulfide (DADS), ajoene, and Sallylmercaptocysteine (SAMC), have been found to induce cell cycle arrest in cancer cells. Alliums have great ethnomedicinal importance as these are used as native remedies against wide spectrum of diseases including diabetes. Allium origin natural products are of great therapeutic and dietary use. These are most preferred items used by nutritionists, physicians, food technologists, food chemists. Green allium vegetables are good source of natural pharmaceutics which are good for health and act against nutritionally induced acute and chronic diseases. Their possible inclusion in diets could explore new therapeutic avenues to enhance immunity against diseases.
\end{abstract}

Keywords: Allium vegetables, antioxidant, cytotoxic, polyphenols, allicin, quercetin.

\section{INTRODUCTION}

The Allium genus includes approximately 500 species. Garlic, onions, shallots, leeks, chives, scallions are most commonly used Allium vegetables throughout the globe in different delicacies (Table 1). Some Allium vegetables have been employed for millenia in the traditional medical practice to treat cardiovascular diseases [1]. All plants in the Allium family are herbaceous, cool season, biennial herbs which are grown as annuals. Root systems are fibrous and shallow as all roots arising from single basal plate. All plants contain fleshy basal leaves that can be tubular or slightly flattened. Bulbs form from enlarged silvery light weight. Allium vegetables and herbs bear wide array of sulfur compounds with characteristic taste, smell, and tear-inducing pungency and show strong antioxidant properties. Green garlic and fresh green, spring onions are mostly preferred by consumers. For vegetable use leaves, flowers, and bulbs are edible. Consumption of these vegetables provides best nutraceuticals which are protective against important life style diseases including cardiovascular, cancer and lipid storage diseases. Allium vegetables contain allylsulfides, polyphenols mainly flavonoids such as quercitin and many of the sulfur compounds have important anti-inflammatory and anti-carcinogenic potential [1]. These also cut

*Address correspondence to this author at the Department of Zoology, D D U Gorakhpur University, Gorakhpur 273009, U.P., India; Tel: 0551-2205616;

Fax: (0551) 2349655; E-mail: rkupadhya@yahoo.com down levels of cholesterol and triglycerides, blood pressure, and give anti-clotting benefits. Allium vegetables are good nutraceutical that are used for cancer prevention and other life style diseases [1]. They are also known to possess antimicrobial, antithrombotic, antitumor, hypolipidaemic, anti-arthritic and hypoglycemic potential.

\section{GARLIC}

Allium sativum, belongs to family Alliaceae and plant order liliales [2]. It is commonly known as lahsun in Hindi (Garlic in English). Garlic had its use since long past prophylactic and therapeutic purposes. Garlic (L.) is important aromatic that contains sulfur compounds [3]. (Figure 1). It is a main singular and combined foodstuff which is used in traditional medicine of India. It was also used for culinary and medicinal purposes by many cultures for centuries [4]. Due to richness of organosulfur compounds, its flavor and aroma is unique and its essential oil and volatiles have potential health benefits [5]. Plant contains wide array of bioorganic components which hold antioxidant, immunomodulating, antimutagenic and antiproliferative properties [6]. Garlic (A. sativum) holds unique therapeutic potential and work against group of pathogens [7]. It shows health promoting properties due to presence of sulfur containing metabolites i.e., allicin and its derivatives [7]. The main active component in garlic is alliin (S-allyl cysteine sulfoxide) which is a potent antioxidant and show cardioprotective and neuroprotective activity. It significantly, cut down 
Table 1: Important Allium Vegetables with their Common Names, Ranges, Characteristics and Uses

\begin{tabular}{|c|c|c|c|c|}
\hline Allium species & Common name & Extent of occurrence & Attribute/s & Uses \\
\hline Allium sativum & Garlic Cultivated & Asia and Eurpoe & Strong flavor & Culinary \\
\hline Allium ursinum & $\begin{array}{l}\text { Wild garlic } \\
\text { naturalized }\end{array}$ & Britain & Mild flavor & Culinary \\
\hline Allium canadense & Meadow garlic & Eastern North America & $\begin{array}{l}\text { Garden culinary } \\
\text { herb }\end{array}$ & Culinary \\
\hline Allium ampeloprasum & Elephant garlic & America and Europe & $\begin{array}{l}\text { Broadleaf, tepals } \\
\text { white, pink or red } \\
\text { strongest flavor }\end{array}$ & $\begin{array}{l}\text { Used as a substitute } \\
\text { for onions }\end{array}$ \\
\hline Allium ascalonium & Shallots & European countries, Israel & $\begin{array}{l}\text { Bulbs grow in } \\
\text { clusters }\end{array}$ & Flavoring \\
\hline $\begin{array}{c}\text { Allium ampeloprasum var. } \\
\text { porrum }\end{array}$ & Leeks & $\begin{array}{l}\text { Southern Europe to western } \\
\text { Asia, eastern North America. } \\
\text { France, Belgium, and the } \\
\text { Netherlands }\end{array}$ & Flashy leaves & $\begin{array}{c}\text { Use in inulinase } \\
\text { production by } \\
\text { Rhodotorula glutinis as } \\
\text { an alternative carbon } \\
\text { source }\end{array}$ \\
\hline Allium schoenoprasum & Chives & European countries & $\begin{array}{l}\text { Insect-repelling } \\
\text { properties }\end{array}$ & $\begin{array}{l}\text { Contains } 4 \text { times } \\
\text { higher contents of } \\
\text { vitamin } C\end{array}$ \\
\hline Allium fistulosum & $\begin{array}{l}\text { Chives hardy } \\
\text { perennial, onion }\end{array}$ & $\begin{array}{c}\text { Chinese chives or Oriental } \\
\text { chives }\end{array}$ & $\begin{array}{l}\text { Mild substitute for } \\
\text { garlic. Bear } \\
\text { pleasant onion } \\
\text { flavor }\end{array}$ & $\begin{array}{l}\text { Used to flavor } \\
\text { vinegars. }\end{array}$ \\
\hline
\end{tabular}

serum levels of glucose, insulin, triglycerides, and uric acid. It also decrease sinsulin resistance, and reduce cytokine levels [9]. Garlic products act on several signaling pathways, including the inflammatory and apoptotic ones, and strongly target cancer [10].

Crushing or chopping of garlic releases an enzyme called alliinase that catalyzes the formation of allicin. Organosulfur compounds from garlic effectively inhibit growth of transplanted as well as spontaneous cancers without any adverse side effects [8]. Organosulfide diallyl trisulfide (DATS) inhibits estrogen receptor- $\alpha$ (ER- $\alpha$ ) activity in human breast cancer cells. Sallylcysteine (SAC) is a water-soluble garlic derivative which acts on human ovarian cancer cells in vitro [11]. SAC treatment significantly reduced the migration of A2780 cells and decreases the protein expression of Wnt5a, p-AKT and c-Jun proteins which are involved in proliferation and metastasis [12]. DATS inhibit matrix metalloproteinase activities and tightening tight junctions [13] and is highly cytotoxic to prostate cancer cells [13]. It inhibits invasion of human bladder carcinoma. DATS, diallyl disulfide (DADS), ajoene, and S-allylmercaptocysteine (SAMC) have been found to induce cell cycle arrest when added to cancer cells in cell culture experiments. Garlic supplementation inhibits platelet aggregation and help in protect against gastric, colorectal cancer (CRC) and relieve from hepatocarcinogenesis [14]. In present review article various uses of Allium vegetables have been explained in detail with its nutraceutical and therepauetic uses. This article also emphasizes multiple biological activity of Allium vegetables against parasites, pathogens, metabolic and life style diseases.

\section{Uses of Garlic}

\section{Culinary Uses}

Both green garlic leaves and bulbs or head spathe are highly edible and are used for various purposes in vegetables. These are used while immature and tender stage (Figure 1). These contain milder flavor than the bulbs. Green garlic is highly used in most dishes to provide spiciness in different regions of the world i.e. 


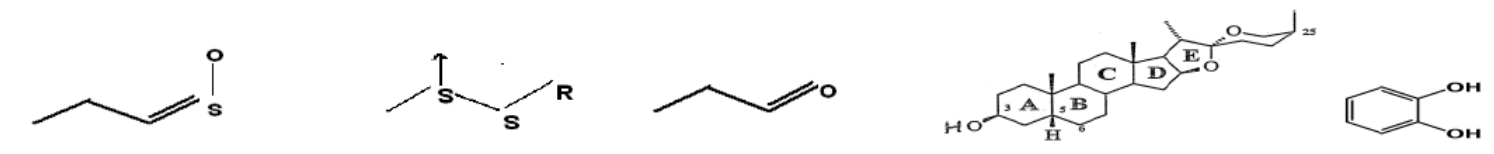

Propanethial -S-oxide

Thiosupfinates

Propanal

Steroidal saponins

Catechol<smiles></smiles><smiles>[R]S[SH]([R])(=O)O</smiles><smiles>CCC[Hg]O</smiles><smiles>[R][SH]O</smiles>

1-propenesulfenic acid

Polysulfides

Thiosulphonates
$\mathrm{H}_{2} \mathrm{C}^{\prime} \mathrm{S}_{\mathrm{S}^{\prime}} \mathrm{S}_{\mathrm{CH}_{2}}$

Diallyl trisulfide

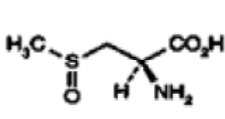

S-methyl

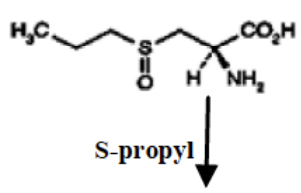

Alling<smiles>C/C=C/S(=O)C[C@H](N)C(=O)O</smiles>

(z)-prop-1-enyl<smiles>C=CCS(=O)CC=C</smiles>

Allicin<smiles>C=CC[S@@](C)(=O)CC(N)C(=O)O</smiles>

Alliin

Sulfenic acids (R-SOH)

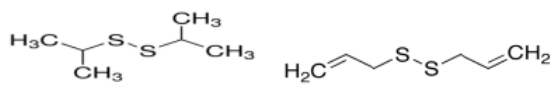

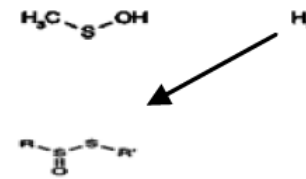

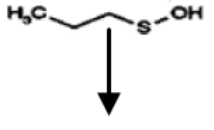

ำ
$\mathrm{H}_{2} \mathrm{C}_{\mathrm{S}^{-O H}}$<smiles>OCC[C+][OH2+]</smiles>

cepaenes

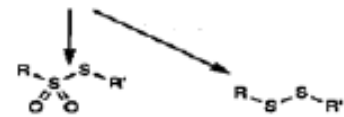

Thiosulfonates disulfides

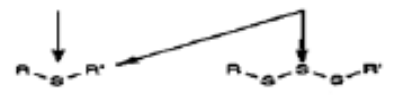

Monosulfides

trisulfides

(Z)-Propanethial oxide

Dipropyl disulfide Diallyl disuphide

$$
\delta_{H} \text { IH }_{O_{H}}
$$

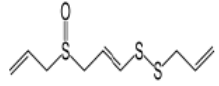

Onion essential oil

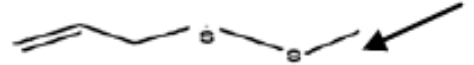

Allyl methyl disulphide

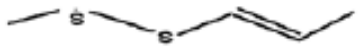

Methyl propenyl disulphide<smiles>C[B]SCSC=CC</smiles>

Methyl propenyl trisulphide<smiles>[CH2][C+](C=[O+][O-])C(C)C=[O+][O-]</smiles><smiles>C=CCN=C=S</smiles>

(Z-Z) 2-3 dimethylbutanedithial S, S' dioxide Allyl isothiocyanate<smiles>C=CCSSCC=C</smiles>

zwiebelanes

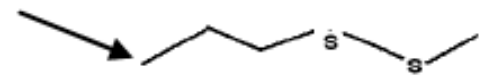

Methyl propyl disulphide

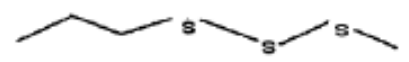

Methyl propyl trisulphide<smiles>CCCS[Hg]CCC</smiles>

Dipropyl disulfide 


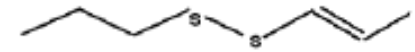

Propyl propenyl disulfide

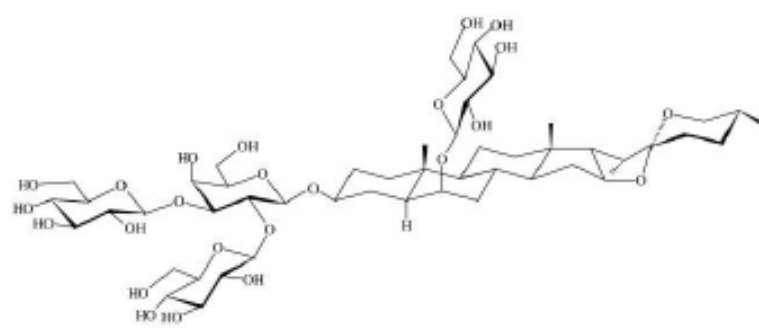

Steroidal saponins

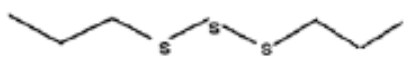

Dipropyl trisulfide

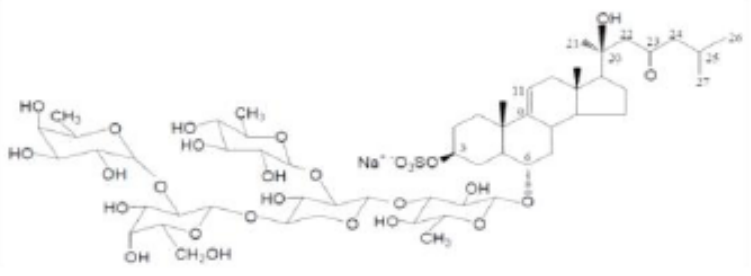

Figure 1: Showing various chemical compounds isolated from Allium species.

Asia, South Asia, Middle East, Northern Africa, Europe and parts of south and Central America. Green garlic is chopped and stir-fried or cooked in soup or hotpot in Southeast Asian mainly in China for preparing cookery. Immature flower stalks are also used in stir-fries. Before using mature garlic bulbs papery, protective layers are removed off before most culinary uses. Garlic flavor varies in intensity and aroma with the ageing of bulbs and different cooking methods. Garlic is used with onion, tomato, or ginger for making dishes and fries. Garlic is a common flavor in foods; it is also used as an additive to prevent food poisoning. Both chopping and processing cause enzymes to break down the compound alliin, found in the cloves, to form allicin. Allicin is the major compound that contributes to chopped garlic's aroma. It too is broken down into a range of sulfur-containing organic compounds, several of which contribute to the "garlic breath" effect. During garlic processing and chopping allicin rapidly breaks down to form a variety of organosulfur compounds. Moreover, cooking inactivate alliinase, therefore, garlic should stand for $10 \mathrm{~min}$ after chopping or crushing before cooking it. Several garlic supplements/products of household or commercial use are available commercially in the market, and each type provides a different profile of organosulfur compounds depending on how it was processed. Garlic essential oil based additives, mouth washers, and fumigants and digestives are sold in different brands [15]. There are single products such as garlic essential oil, garlic oil macerate, garlic powder, and garlic extract sold as single herb category (Table 1). The manufacturing process is an important consideration when choosing a garlic supplement for household or commercial use. Steroid saponins and sapogenins present in garlic bulbs are used to prepare soft soaps. $\beta$-chlorogenin is a characteristic steroid sapogenin from garlic that is used for skin ointment and as a shiner. Both garlic paste and soft garlic preparations are used for flavoring the food items. Garlic products that contain the most safe, effective, stable, and odorless components are the most valuable as dietary supplements. Garlic also contains non sulfur compounds such as steroid saponins. These have characteristic properties, including the production of stable foam when shaken with water, hemolytic activity, and a bitter taste. Garlic preparations differ in their ingredients, effects, toxicities and trade name. Garlic natural products of therapeutic and dietary use are most preferred items used by nutritionists, physicians, food technologists, food chemists. Raw garlic or half processed garlic pastes are used as pharmaceuticals for maintaining health and act against nutritionally induced acute and chronic diseases.

\section{Therapeutic Uses}

Garlic shows very high therapeutic potential against various diseases such as hyperlipedemia and atherosclerosis related vascular changes. Fresh garlic juice, aged, garlic extract or volatile oil are used to cut down cholesterol and plasma lipids. Dietary use of garlic restores cardiovascular functions of heart and blood transport system. It effectively cut down the development of atherosclerosis and reduces blood pressure, removes hardening of the arteries. It also cut down high cholesterol level, and thereby reduces the risk of coronary heart diseases and even provide safety from heart attack. Garlic and its derivatives also reduce the risk of various types of human cancer [12]. Locals 
use garlic products to prevent colon cancer, rectal cancer, cancer, breast, prostate cancer, and lung cancer. The overall activity of garlic is mainly due to the presence of sulfur compound such as alliin, allicin, ajeone and others. Garlic and its flavor volatiles/active compounds found effective in reducing cardiovascular and metabolic risk by normalizing abnormal plasma lipids, oxidized low density lipoproteins (LDLs), abnormal platelet aggregation, high blood pressure, and cardiac injury. Garlic has the potential to protect the heart against myocardial infarction; garlic essential oil shows anti-atherosclerotic effect [16]. It also decreases the doxorubicin-induced cardiotoxicity, arrhythmia, hypertrophy, and ischemia-reperfusion injury. Garlic contains many functional groups that may act as cardiac endogenous antioxidants and lower down the lipid peroxidation. Other mechanisms, such as regulating ion channels, modulating Akt signaling pathways, histone deacetylase inhibition, and cytochrome P450 inhibition, could be responsible for the cardioprotective effect of garlic. Garlic showed positive effects on an enlarged prostate benign prostatic hyperplasia (BPH), diabetes, osteoarthritis, hay fever (allergic rhinitis), traveler's diarrhea, high blood pressure late in pregnancy (pre-eclampsia), cold and flu. It is also used for toning up immune system, preventing tick bites, and preventing and treating bacterial and fungal infections (Table 2).

Garlic shows beneficial effects against a wide spectrum of diseases, including cancer and diabetes. It provides relief from microbial infections, as well as immunological and cardiovascular disorders. It is actively used for the treatment of fever, coughs, headache, stomach ache, sinus congestion, rheumatism, hemorrhoids, asthma, and gout, shortness of breath, bronchitis, low blood pressure and blood sugar, high blood sugar and snakebites. It is also used for fighting stress and fatigue, and treatment of cancer and liver related diseases [14, 17]. Garlic oil is used for the treatment of skin fungal infections, warts, and corns. Garlic ointment is topically used for control of fungal infections like ringworm, jock itch, and athlete's foot. The smelly secondary metabolites from garlic serve two important functions serve as defense against predators, parasites and diseases.

DATS is a major organosulfur compound isolated from garlic ( $A$. sativum $\mathrm{L}$.). It inhibits cell proliferation by triggering either cell cycle arrest or apoptosis [18]. DATS shows pro-apoptotic activity which is regulated by a caspase-dependent cascade through the activation of both intrinsic and extrinsic signaling pathways. These are mediated through the blocking of PI3K/Akt and the activation of the JNK pathway [18]. There is a lot of variation among garlic products sold for medicinal purposes. Garlic's distinctive odor, depends on the method of preparation. But amount of allicin provides it commercial value as it is unstable, and changes into a different chemical rather quickly. Some manufacturers take advantage of this by aging garlic to make it odorless. Some odorless garlic preparations and products may contain very little, or no allicin it depends on garlic processing. Amount of allicin and its effectiveness of the product are two important parameters of herbal care products. In dietary methods crushing the fresh clove release more allicin, hence delayed processing remove out burning taste. Some products have a coating (enteric coating) to protect them against attack by stomach acids (Table 1 ).

\section{Pharmaceutical Uses}

Garlic is used as herbal supplements in cooked foods available throughout the world and has many many health benefits. Garlic contains four major compounds i.e., DADS, allyl methyl sulfide, allyl mercaptan, and allyl methyl disulfide. Among which allyl methyl sulfide is the compound that takes longest for the body to break down. It is absorbed in the gastrointestinal tract and passes into the bloodstream, then passes on to other organs in the body for excretion, specifically the skin, kidneys and lungs. Due to presence of functionally active organosulfur compounds such as allin, DADS, SAMC, and S-trityl-Icysteine garlic has received great attention from a large number of pharmaceutical companies because of its broad spectrum disease curing potential. Garlic derived organosulfur compounds are able to prevent development of cancer, cardiovascular, neurological, and liver diseases as well as allergy and arthritis [19]. Dietary garlic shows protective effects $[19,20]$ and is a well known herbal remedy for removing nephrotoxicity lipid lowering, platelet, fibrinolytic and vascular effects [21]. Green garlic is strong antidiabetic and cardiovascular agent that restores the insulin level and cut down extra concentration of lipids from the body.

Allium vegetables reduce the risk of prostate cancer [22] but its higher intake is harmful [23]. Garlic contains allicin that shows antimicrobial and anticancer activity [24]. Organosulfur compounds from garlic are used to prevent and treat chronic diseases, such as cancer and cardiovascular disease. Green garlic is hepatoprotective, and shows immunomodulation and anti-inflammatory effects. It inhibits proliferation of 
Table 2: Therapeutic Use of Various Plant Parts Allium cepa and Allium sativum Against Different Diseases

\begin{tabular}{|c|c|c|c|c|c|}
\hline $\begin{array}{l}\text { Plant part of } \\
\text { Allium cepa }\end{array}$ & $\begin{array}{l}\text { Preparation/ } \\
\text { Ailment }\end{array}$ & Treatment & $\begin{array}{l}\text { Garlic (Allium } \\
\text { sativum }\end{array}$ & $\begin{array}{l}\text { Preparation/ } \\
\text { Ailment }\end{array}$ & Treatment \\
\hline Leaves & $\begin{array}{l}\text { Cold water } \\
\text { concoction }\end{array}$ & $\begin{array}{c}\text { Diarrhea, gastroenteritis } \\
\text { problems }\end{array}$ & Leaves & $\begin{array}{c}\text { Hot } \\
\text { concoction }\end{array}$ & $\begin{array}{l}\text { Reduce serum total cholesterol } \\
\text { and triglyceride levels }\end{array}$ \\
\hline Leaves & Green paste & $\begin{array}{l}\text { Reduce serum total cholesterol } \\
\text { and triglyceride levels }\end{array}$ & Leaves & Tea & $\begin{array}{c}\text { Reduce platelet aggregation, } \\
\text { hyperlipidemia }\end{array}$ \\
\hline Bulbs green & Crushed paste & $\begin{array}{c}\text { Reduce platelet aggregation, } \\
\text { hyperlipidemia }\end{array}$ & Bulbs green & $\begin{array}{l}\text { Crushed } \\
\text { paste }\end{array}$ & Blood-thinning \\
\hline Leaves & Oil & Blood-thinning & Leaves & Oil & $\begin{array}{l}\text { Adhesive in mending glass and } \\
\text { porcelain }\end{array}$ \\
\hline Bulb & Sticky juice & $\begin{array}{c}\text { Adhesive in mending glass and } \\
\text { porcelain }\end{array}$ & Bulb & Sticky juice & $\begin{array}{l}\text { Nematicide and insecticide for } \\
\text { cabbage root fly and red mite in } \\
\text { poultry, used to deter animals } \\
\text { such as birds, insects and worms } \\
\text { from herbivory }\end{array}$ \\
\hline Bulb & $\begin{array}{c}\text { Solvent } \\
\text { extract }(w / v)\end{array}$ & $\begin{array}{l}\text { Anti-parasitic and show } \\
\text { repellent effects against flies } \\
\text { and mosquitoes. }\end{array}$ & Bulb & $\begin{array}{c}\text { Solvent } \\
\text { extract }(w / v)\end{array}$ & $\begin{array}{l}\text { Relieving pain, defense against } \\
\text { malaria, flu, cold and sneezing }\end{array}$ \\
\hline Folk medicine & $\begin{array}{l}\text { Crushed bulbs } \\
\text { and dry stem }\end{array}$ & $\begin{array}{l}\text { Relieving pain, defense against } \\
\text { malaria, flu, cold }\end{array}$ & Folk medicine & $\begin{array}{l}\text { Crushed } \\
\text { bulbs and } \\
\text { dry stem }\end{array}$ & $\begin{array}{l}\text { Expectorant for coughs, sneezing } \\
\text { deterring animals such as birds, } \\
\text { insects, and worms from eating } \\
\text { the plant. }\end{array}$ \\
\hline Leaves & Hot syrup & $\begin{array}{l}\text { Used as expectorant for coughs } \\
\text { and constipation }\end{array}$ & Cherokee & Hot syrup & Antiseptic and prevent gangrene \\
\hline Bulb & $\begin{array}{l}\text { Luke warm } \\
\text { paste }\end{array}$ & Antiseptic to prevent gangrene & Bulb & $\begin{array}{l}\text { Luke warm } \\
\text { paste }\end{array}$ & $\begin{array}{l}\text { Fish and meat and preservative, } \\
\text { and antimicrobial }\end{array}$ \\
\hline Onion + mint & Bulb and bark & $\begin{array}{l}\text { Fish and meat preservative, and } \\
\text { antimicrobial }\end{array}$ & $\begin{array}{l}\text { Garlic + } \\
\text { cinnamon }\end{array}$ & $\begin{array}{l}\text { Bulb and } \\
\text { bark }\end{array}$ & Both good and evil \\
\hline $\begin{array}{l}\text { Spiritual and } \\
\text { religious }\end{array}$ & Total plant & $\begin{array}{l}\text { Use for keep away bad air, } \\
\text { demons and evils }\end{array}$ & Total plant & $\begin{array}{l}\text { Spiritual and } \\
\text { religious }\end{array}$ & White magic \\
\hline Europe & Bulbs & Lighten the balance of the blood & Bulbs & Europe & $\begin{array}{l}\text { Powerful ward against demons, } \\
\text { werewolves and vampires }\end{array}$ \\
\hline $\begin{array}{l}\text { Central } \\
\text { European }\end{array}$ & Onion bulbs & $\begin{array}{l}\text { Pay their rent with onions, and } \\
\text { even give them as gifts }\end{array}$ & $\begin{array}{l}\text { Total garlic } \\
\text { plant could be } \\
\text { worn, hung in } \\
\text { windows, or } \\
\text { rubbed on } \\
\text { chimneys and } \\
\text { keyholes }\end{array}$ & $\begin{array}{l}\text { Central } \\
\text { European }\end{array}$ & Good for prayer \\
\hline Muslims & Green onion & Good for prayer & $\begin{array}{l}\text { Green and raw } \\
\text { garlic }\end{array}$ & $\begin{array}{l}\text { Most of the } \\
\text { West Asian } \\
\text { countries }\end{array}$ & Metabolic stimulant \\
\hline Hinduism & $\begin{array}{l}\text { Green and } \\
\text { raw onion }\end{array}$ & $\begin{array}{l}\text { Prescribe to facilitate bowel } \\
\text { movements and erections, and } \\
\text { to relieve headaches, coughs, } \\
\text { snakebite and hair loss }\end{array}$ & $\begin{array}{l}\text { Green and raw } \\
\text { garlic }\end{array}$ & $\begin{array}{l}\text { India, } \\
\text { Pakistan, } \\
\text { Cambodia, } \\
\text { Bangladesh }\end{array}$ & $\begin{array}{l}\text { Religion avoids eating garlic and } \\
\text { onion on a daily basis. }\end{array}$ \\
\hline Jain & $\begin{array}{l}\text { Green and } \\
\text { raw onion }\end{array}$ & Religion avoid eating onions & $\begin{array}{l}\text { Green and raw } \\
\text { garlic }\end{array}$ & $\begin{array}{l}\text { All Asia and } \\
\text { Europe }\end{array}$ & $\begin{array}{l}\text { Increase drives to the detriment of } \\
\text { meditation practice }\end{array}$ \\
\hline $\begin{array}{l}\text { Buddhist } \\
\text { traditions }\end{array}$ & $\begin{array}{l}\text { Green and } \\
\text { raw onion }\end{array}$ & $\begin{array}{l}\text { Increase drives to the detriment } \\
\text { of meditation practice. }\end{array}$ & Salads & Buddhist & $\begin{array}{l}\text { To make syrups, form poultices } \\
\text { and in the preparation of dyes }\end{array}$ \\
\hline
\end{tabular}

cancer cell. Garlic exhibits hypolipidemic, anti-platelet, and procirculatory effects. It prevents cold and flu symptoms through immune enhancement. Dietary consumption of garlic mainly aged garlic gives therapeutic potency [25] (AGE) because it attributes wide variety of biological activities. AGE also has hepatoprotective, neuroprotective, and antioxidative activities, whereas other preparations may stimulate oxidation [26]. Important biological effects of garlic may be due to conversion of compounds that are formed 
during AGE's long-term extraction process (Table 2). Dietary use of garlic restores immune function and prevents cancer. Garlic and its components possess following pharmaceutical activities.

\section{Antidiabetic and Cardiovascular}

Garlic is highly beneficial for diabetic patients [27, 28] as it contains fructo-oligosaccharides which replaces normal sugar [29] Homemade green garlic preparations are good protective ailments which prevent cardiovascular diseases [30] Garlic shows multiple protective effects and improves functioning of cardiovascular system [31-33]. It removes off atherosclerosis and does reduction of serum lipids [30]. It shows inhibition of platelet aggregation and enhancement of fibrinolysis. Wild garlic (Allium ursinum) has been reported to contain similar amounts of sulfur-containing compounds [34] (thiosulfinates and ajoenes) which exert similar effects on cyclooxygenase, 5-lipoxygenase, angiotensin converting enzyme, and platelet aggregation [34, 35]. Effect of DADS on insulin-like growth factor signaling molecules involved in cell survival and proliferation of human prostate cancer cells in vitro and in silico approach through docking analysis [36].

\section{Lipid-lowering Effects}

Garlic products showed positive effects on lipid metabolism [37] and cut down lipid contents in experimental animals [38-40]. Possibly it may occur via inhibition of 3-hydroxy-3-methyl-glutaryl-CoA reductase or other enzymes [41-44]. More specifically, garlicderived organosulfur diallyl di- and trisulphide compounds inhibit cholesterol biosynthesis in primary rat hepatocyte cultures [45, 46]. Moreover, garlic ingredients increase loss of bile salts in feces and mobilization of tissue lipids into circulation [47]. Garlic does lowering of blood lipids, blood sugar, and fibrinogen and induces fibrinolytic activity in patients with coronary artery diseases. Garlic essential oil shows profound effect on post-prandial hyperlipidemia and does prevention of atherosclerosis [48].

\section{Phytochemistry}

Garlic ( $A$. sativum) bulbs contain large amount of carbohydrates, glycosides and proteins. These also contain alkaloids, saponins, reducing sugars, oils and steroids in medium concentrations. Both green garlic and raw dry garlic contains flavonoids and acidic compounds in low amounts. Both green and aged garlic contains many sulfur-containing compounds which provide it a characteristic flavor. These sulphur- containing compounds are diallyl sulphate, alliin, ajoene, allicin. From garlic two categories of compounds oil- and water-soluble are isolated. Oilsoluble compounds are sulfides, such as DAS, DADS, DATS and allyl methyl trisulfide, dithiins, and ajoene. Few water-soluble cysteine derivatives are S-allyl cysteine (SAC), SAMC and S-methyl cysteine, and gamma-glutamyl cysteine [10] (Figure 2). Oil-soluble sulfur compounds possess characteristic odor, whereas water-soluble compounds are odorless. Moreover, water-soluble compounds are more stable and safer than oil-soluble compounds [49]. DADS, the major organosulfur component of processed garlic is very effective in chemoprevention of several types of cancers [50] Table 3.

Garlic essential oil contains important sulfur compounds such as DAS, DADS, DATS, methylallyl disulfide, methylallyl trisulfide, 2-vinyl-4H-1, 3-dithiin, 3vinyl-4H-1, 2-dithiin, and (E,Z)-ajoenes (Figure 2). DAS, DADS, and DATS are major volatile components of garlic oil $[50,115]$. Some other chemical constituents like allylmethyl (37\%), and dimethyl (6\%) mono- to hexasulfides allyl 1-propenyl and methyl 1-propenyl di-, tri-, and tetrasulfides found in trace amounts in garlic. DAS and vinyldithiins are the major organosulfur components of garlic oil and oil-macerate preparations. Vinyldithiins, especially 2-vinyl-4H-1, 3-dithiin, are rich in the oil macerate of raw garlic [49]. Garlic contains ajoene a much potent antithrombotic agent [50].

Garlic also contains non sulfur compounds such as steroid saponins and sapogeneins which work as reliable chemical markers for the identification of garlic and garlic preparations, except for garlic oil. Another ajoene-type organosulfur compound, E-4,5,9tritriadeca-1,7-diene-9-oxide, is also isolated from oilmacerated garlic extract [51] Table 3. $\beta$-chlorogenin is a characteristic steroid sapogenin of garlic. Two categories of saponins i.e., triterpenoid saponins and steroid saponins, based on the molecular structure of aglycone [52]. Important steroid saponins isolated from the garlic bulb are eruboside-B, proto-eruboside-B [53]. Other steroid saponins are furostanol saponins and spirostanol saponins. Garlic contains allixin and organo-selenium compounds which show synergistic action better that organosulfur compounds. Garlic supplement products are very popular among consumers are available in the market [54]. Many of them are the most popular herbal supplement included in the single herb category. There are dozens of brands of garlic products on store shelves that provide a convenient way to obtain the health benefits of garlic. 
Table 3: Nutritional Value of Chemical Components Garlic Allium cepa and Allium sativum

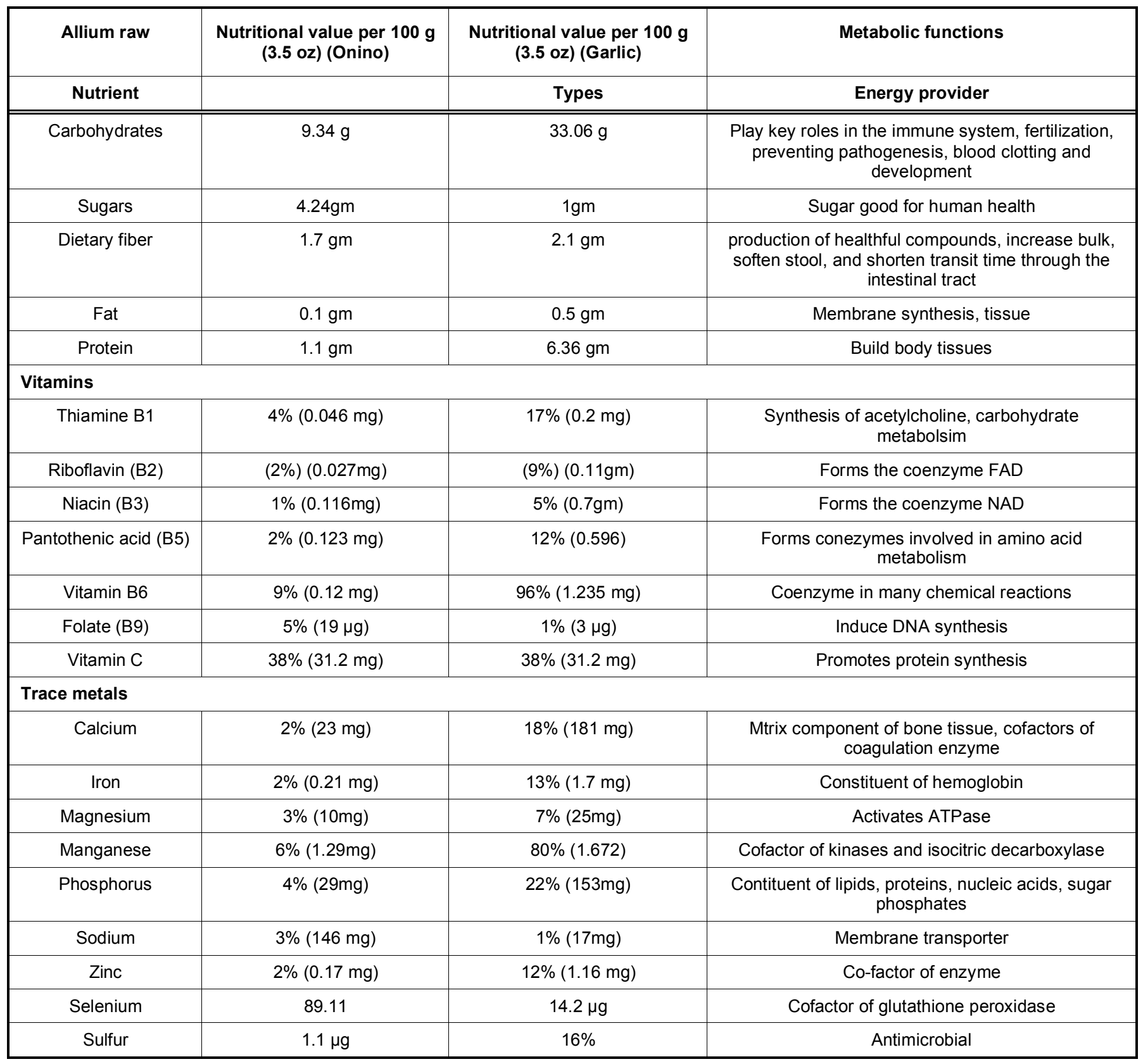

$\mu \mathrm{g}=$ micrograms, $\mathrm{mg}=$ milligrams, $\mathrm{IU}=$ International units, Percentages are roughly approximated, ${ }^{* \star}$ Garlic bulbs contain approximately $84.09 \%$ water, $13.38 \%$ organic matter, and $1.53 \%$ inorganic matter, while the leaves are $87.14 \%$ water, $11.27 \%$ organic matter, and $1.59 \%$ inorganic matter.

Few important products are garlic essential oil, garlic oil macerate, garlic powder, and garlic extract (Table 2). Garlic essential oil is available in the form of additive, mouthwashner, and fumigant and digestive. The manufacturing process is an important consideration when choosing a garlic supplement for household or commercial use. Steroid saponins and sapogenins present in garlic bulbs are mixed in soft soaps. $\beta$ chlorogenin is a characteristic steroid sapogenin from garlic that is used for skin ointment and as a shiner. Both garlic paste and soft garlic preparations are used for flavoring the food items. The various forms also differ in their ingredients, effects, and toxicities. Garlic products that contain the most safe, effective, stable, and odorless components are the most valuable as dietary supplements [55]. Garlic also contains non sulfur compounds such as steroid saponins. These have characteristic properties, including the production of stable foam when shaken with water, hemolytic activity, and a bitter taste (Table $\mathbf{3}$ ).

Intact garlic contains water-soluble organosulfur compounds such as $\mathrm{Y}$-glutamyl-S-allyl-L-cysteines and S-allyl-L-cysteine sulfoxides (alliin) as major sulfur 
containing compounds. Both found in higher concentration. In aged garlic extract both S-Allyl-Lcysteine and trans-S-1-propenyl-L-cysteine in ample amount while S-methyl-L-cysteine found in small amount [51]. Alliin is the primary odorless, sulfurcontaining amino acid, a known precursor of allicin [52], methiin, (+)-S-(trans-1-propenyl)-L-cysteine sulfoxide, and cycloalliin [51]. Transformation of cysteine sulfoxides to sulfenic acid (Figure 1) takes place in presence of alliinase. This enzyme acts at $\mathrm{pH}$ optimum of 6.5 by using S-methyl-L-cysteine as substrate molecule [53]. After its formation sulfenic acids spontaneously react with each other to form unstable compounds called thiosulfinates. This reaction occurs in cytoplasm in the presence of enzyme alliinase inside vacuole, via sulfur-substituted sulfenic acids (Figure 1).

Other thiosulfinates, such as allylmethyl-, methylallyl-, and trans-1-propenyl-thiosulfinate, are also formed during garlic homogenization. These are also unstable like allicin [54, 55]. In addition, pyridoxal phosphate acts as a cofactor that stimulates alliinase activity [56]. Thiosulfinates are formed during processing or chopping or crushing of garlic very rapidly within 10-60 s but these are not formed below $\mathrm{pH} 3.6$, which is the usual $\mathrm{pH}$ range in the stomach [57] (Table 3).

Garlic root bulbs are rich in sulfur compounds such as allicin that breaks down in vitro to form a variety of fat-soluble organosulfur compounds (Figure 1). Allicin is highly temperature sensitive and decompose in to DATS, DADS, and DAS sulfur dioxide if it is kept at $20^{\circ} \mathrm{C}$ for $20 \mathrm{~h}$ [58]. This decomposition also takes place in the presence of oil or organic solvents. Alliin is a water soluble compound which is absorbed inside the body but never converted to allicin in the body and metabolized to various organosulfur compounds such as DADS by liver enzymes [59]. Allicin easily reacts with amino acids and proteins, creating a - $\mathrm{SH}$ group, and cannot circulate in the blood stream [60] that is why it is not detected in the blood sample after the ingesting raw garlic or pure allicin (Table 3) [61]. Allicin is an irritating, acidic, and oxidizing compounds being used as a therapeutic agent. Garlic also contains a variety of components, including nonsulfur compounds, work synergistically to provide various health benefits (Table 4). Processed garlic contains a wider variety of organo-sulfur volatiles than the intact garlic clove.

Garlic also contains water soluble compounds such as SAC. These are formed from gammaglutamylcysteines during long-term incubation of crushed garlic in aqueous solutions, as in the manufacture of aged garlic extracts. Few nonvolatile sulfur containing precursors also found in intact garlic. These are $\mathrm{Y}$-Glutamyl-S-allyl-L-cysteines which are converted into S-allyl-cysteines (SAC) through an enzymatic transformation with $\mathrm{Y}$-glutamyltranspeptidase when garlic is extracted with an aqueous solution [62]. SAC, a major transformed product from $y$ glutamyl-S-allyl-L-cysteine, is a well known chemical marker which is scientifically reasonable and well justified. Moreover, sulfides having an allyl group provide characteristic smell and taste after ingesting garlic. These are detected in the blood samples in orally administered experimental animals (Table 3 ).

\section{Onion: Allium cepa}

\section{Nutraceutical and Dietary Uses}

Onions are multipurpose foods which possess high nutraceutical value. Onion ingredients are used to prepare various hearty warm dishes, salads, soup or chutney or used in pickles for flavor. Green onions are used in vegetables, while dried are baked, boiled, braised, grilled, fried, roasted, sautéed or eaten raw in salads [63]. Onions are used as a thickening agent for curries and gravies. These are used as material in Indian cuisine and dip in vinegar to eat as snack. Green onions are sliced, chopped, battered and deep fried in oil to prepare many dishes, pubs and fish fries [64]. Yellow and red onions are considered best for preparing soup because of its sweet flavor. Spring onions are most likely used in making vegetable flavor and of a different taste. Pink and red onions are preserved in vinegar as a long-lasting relish. Eating of green raw onions is quite beneficial because cooked onions in vegetable may loss many active ingredients [64]. White onions are the traditional onions that are used in classic Mexican cuisine. These give rise golden color and a sweet flavor after being cooked [64].

Alliums contain ecologically favoring phytochemicals which are suitable for health and hygiene. Onions are nutritionally rich and contain good percentage of water, sugar, protein, fibre, vitamins and fats. Most onion cultivars are about $89 \%$ water, $4 \%$ sugar, $1 \%$ protein, $2 \%$ fibre and $0.1 \%$ fat. Onions are best source of vitamin $\mathrm{C}, \mathrm{B} 6 \mathrm{~K}$, folic acid and numerous other nutrients in small amounts. These are low in fats and in sodium, possess an energy value of $166 \mathrm{~kJ}$ (40

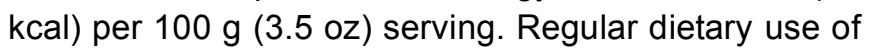
raw alliums lower down toxigenicity of oils [65], and reduce the risk of gastric cancer [66]. Allium cepa L. 


\section{Table 4: Biological Activity of Phytochemicals Isolated from Plants of Allium Family}

\begin{tabular}{|c|c|c|}
\hline Onion components & Characteristics/attributes & Biological activity \\
\hline Acetal (bulb) & & No activities reported. \\
\hline Allyl propyl-disulfide (bulb). & A sulfur-containing compound & $\begin{array}{c}\text { Biological activities are hypoglycemic, insulin-sparing and occuloirritant. } \\
\text { There are } 2 \text { species listed with this constituent. Allium cepa is second after } \\
\text { garlic }\end{array}$ \\
\hline $\begin{array}{l}\text { Proteins, minerals, } \\
\text { saponins, flavonoids, } \\
\text { enzymes, B vitamins }\end{array}$ & Non sulfur compounds & Anticarcinogenic \\
\hline Allyl methyl sulfide & $\begin{array}{l}\text { After food intake onion strong- } \\
\text { smelling sulfur compounds are } \\
\text { metabolized, forming allyl } \\
\text { methyl sulfide. }\end{array}$ & $\begin{array}{l}\text { Abundant sulfur compounds in garlic responsible for turning garlic green or } \\
\text { blue during pickling and cooking. Act as mosquito repellent. }\end{array}$ \\
\hline $\begin{array}{l}\text { Cyanidin-diglycoside } \\
\text { (bulb) }\end{array}$ & & No activities reported \\
\hline Diallyl sulfide & $\begin{array}{l}\text { A onion derived organosulfur } \\
\text { compound }\end{array}$ & $\begin{array}{c}\text { Prevents tumor progression and promotes apoptosis in ectopic glioblastoma } \\
\text { xenograft, prevent growth of pancreatic cancer cells }\end{array}$ \\
\hline Diallylpolysulfides & organosulfur compound & diallylpolysulfides induce growth arrest and apoptosis in cells \\
\hline diallyltetrasulfide (DATTS) & organosulfur compound & Induce mitotic arrest to apoptosis \\
\hline $\begin{array}{l}\text { gamma-glutamylcysteines, } \\
\text { Allylcysteine sulfoxide } \\
\text { (alliin) }\end{array}$ & organosulfur compound & Generate hot odor \\
\hline Allyl sulfides & organosulfur compound & $\begin{array}{l}\text { Inhibit cell growth of skin cancer cells through induction of DNA damage } \\
\text { mediated G2/M arrest and apoptosis. }\end{array}$ \\
\hline S-allylcysteine & organosulfur compound & acts on human ovarian cancer cells in \\
\hline S-allylmercaptocysteine & organosulfur compound & induce cell cycle arrest and reduce the risk of various types of human cancer. \\
\hline S-alkenylmercaptocysteine & organosulfur compound & Induce apoptosis in pancreatic cells \\
\hline $\begin{array}{c}\text { Garlicnins } B(1), C(1) \text {, and } \\
D\end{array}$ & Sulfur containing compounds & Highly toxic to cancer cells \\
\hline S-allylmercaptocysteine & $\begin{array}{l}\text { active organosulfur } \\
\text { compounds }\end{array}$ & Highly toxic to cancer cells \\
\hline S-allylcysteine, & $\begin{array}{l}\text { active organosulfur } \\
\text { compounds }\end{array}$ & $\begin{array}{c}\text { Suppresses proliferation and induces apoptosis in human ovarian cancer } \\
\text { cells in vitro. reduced the migration of A2780 cells and decreases the protein } \\
\text { expression of Wnt5a, p-AKT and c-Jun proteins which are involved in } \\
\text { proliferation and metastasis }\end{array}$ \\
\hline
\end{tabular}


(Table 4). Continued.

\begin{tabular}{|c|c|c|}
\hline Onion components & Characteristics/attributes & Biological activity \\
\hline Polysulfanes & Sulfur containing compounds & Possess antimicrobial, chemopreventive and anticancer properties. \\
\hline Glycolic acid (bulb) & Chemopreventive & Cholesterolic, diuretic, hepatonic and irritant \\
\hline Kaempferol (bulb) & Chemopreventive & $\begin{array}{c}\text { Antiaggregant, antiallergic, antibacterial, anticancer, antihistaminic, } \\
\text { antigingivitic, antiinflammatory, antioxidant, antiplaque, antiulcer, antiviral, } \\
\text { hepatoprotective and vasodilator }\end{array}$ \\
\hline $\begin{array}{l}\text { Methyl-propenyl- } \\
\text { trisulphide (plant), Methyl- } \\
\text { propyl-disulfide (bulb), } \\
\text { Methyl propyl-trisulfide } \\
\text { (bulb) }\end{array}$ & No action & No activities reported. \\
\hline Oleanoic acid (bulb) & Chemopreventive & $\begin{array}{l}\text { AntiHIV, antiallergic, antiatherosclerotioc, antibacterial, antigingivitic, } \\
\text { antiinflammatory, antioxidant, antiviral, antitumor and cardioprotectiv }\end{array}$ \\
\hline Potassium (bulb) & Active ion & $\begin{array}{l}\text { Antiarrhythmic, antidepressant, antifatigue, antihypertensive, antispasmodic, } \\
\text { diuretic and vasodilator }\end{array}$ \\
\hline Pyrocatechol (bulb) & Chemopreventive & $\begin{array}{l}\text { Anticancer (breast), antihepatotoxic, antioxidant, antiseptic, CNS-stimulant, } \\
\text { cardiovascular, dermatitigenic, dye, insectifuge, nematicide and quinone- } \\
\text { reductase-reducer }\end{array}$ \\
\hline Pyruvic acid (fruit) & Flavor activity & Dietary functions \\
\hline Quercitin (bulb) & Chemopreventive & $\begin{array}{c}\text { Analgesic, antiCrohn" s, antiGTF, antiHIV, antiPMS, antiaggregant, } \\
\text { antiaging, antiallergic, antialzheimeran, antiarthritic, antiasthmatic, } \\
\text { antiatherosclerotic, antibacterial, anticataract, anticystitic, antidepressant, } \\
\text { antidermatic, antiflu, antigastric, antihistaminic, antiinflammatory, antimalarial, } \\
\text { antioxidant, antipancreatic, antiplaque, antipolio, antispasmodic, antitumor, } \\
\text { antiulcer }\end{array}$ \\
\hline $\begin{array}{l}\text { Quercetin-3-beta-D- } \\
\text { glucoside (bulb) }\end{array}$ & Chemopreventive & Antiinflammatory and cancer-preventive. \\
\hline Riboflavin & Chemopreventive & Anticataract and antimigraine \\
\hline $\begin{array}{l}\text { S-methyl-cysteine- } \\
\text { sulfoxide (bulb) }\end{array}$ & Chemopreventive & antidiabetic and antihypercholesterolemic activities \\
\hline Succinic acid (bulb) & Chemopreventive & $\begin{array}{c}\text { Allium cepa is number eight on the plant species list with the highest amount } \\
\text { of this constituent. }\end{array}$ \\
\hline Vanillic acid & Chemopreventive & $\begin{array}{l}\text { Anthelmintic, antibacterial, anticancer, antifatigue, antiinflammatory, } \\
\text { antiseptic, antitumor, cancer-preventive and laxative }\end{array}$ \\
\hline Allium ascalonium & $\begin{array}{c}\text { Di-2-propenyl trisulfide } \\
(31.8 \%) \text {, diallyl disulfide } \\
(28.4 \%), \text { and dipropyl trisulfide } \\
(8.4 \%)\end{array}$ & anticancer, antifatigue, antiinflammatory, antiseptic \\
\hline $\begin{array}{l}\text { Allium ampeloprasum var. } \\
\text { porrum }\end{array}$ & $\begin{array}{c}\text { by dipropyl trisulfide (15.01\%), } \\
\text { methyl propyl disulfide } \\
(4.48 \%), 1 \text {-propenyl propyl } \\
\text { disulfide }(3.75 \%) \text { and methyl } \\
\text { propyl trisulfide }(3.19 \%) .\end{array}$ & antiseptic sulfur oil as their onion cousins. \\
\hline Allium schoenoprasum & $\begin{array}{l}\text { Isopropyl disulfide, methyl } \\
\text { pentyl disulphide, } \\
\text { penthanethiol, penthyl- } \\
\text { hydrosulfide and cis/trans-3,5- } \\
\text { diethyl-1,2,4-trithiolane. }\end{array}$ & Chives is a good source of vitamin $\mathrm{C}$ and strong anti-oxidant. \\
\hline
\end{tabular}

shows inhibitory effects on proliferation of cancer cells and adipocytes via inhibiting fatty acid synthase [67]. In hot summer use of onions check fast dehydration of body and assist in release of excessive heat [68]. It is used as a white vegetable known as a forgotten source of nutrients $[69,70]$. It contains minerals and trace elements (zink) of high nutritive value and considered to be a healthy meal [70]. Its daily use in diet restore zinc deficiency [71]. It contains polyphenol content [72] which lower down effect of UV radiation on shoot tissue pigment in Allium fistulosum L. cultigens [73. Onion peel extracts ameliorate hyperglycemia and insulin 
resistance in high fat diet/streptozotocin-induced diabetic rats [74].

Onions traditionally are used in Indian spices mainly for adding flavour to savoury dishes [75, 76]. Use of onions in salads reduces plasma LDL cholesterol level because it contains flavonols, flavones and isoflavones [77]. Dietary intake of white vegetables mainly Alliums reduce the risk of spontaneous preterm delivery [78], glycemia and satiety [79]. Onions are healthy food material that has great health significance at global level [80]. Onion peel extracts remove out problem of hyperglycemia [74] and kill enterotoxigenic bacteria [81, 82]. Nutritional intake of onions increases learning potential in students83. S-alk(en)yl-L-cysteine sulfoxide and dimethyl sulfone are important dietary biomarkers of onion intake [85]. Allium vegetables show strong antioxidants capacity $[86,87]$ that lost after cooking. Both quality and nutritional values of white vegetables could restore by using low-dose radiation [87]. Onions are also used for vinegar production [88]. Water solution of onion crude powder inhibits RANKL-induced osteoclastogenesis through ERK, p38 and NF-kappaB pathways [89]. Presence of flavonoids in onions prevent intestinal neoplasia [90]. High selenium and phenolic contents show varietal difference in antioxidant, anti-inflammatory, anti-cholesterol, anticancer, anti-lipimdemic and antiproliferative activities of onions [92]. Onion is also a good nutrition for animals and other veterinarians. These contain short-chain fructooligosaccharides whch display high nutritive values [93]. Dietary intakes of flavonols, flavones, isoflavones and quercetin intake reduce plasma LDL cholesterol concentration [77]. Onions contain good amount of anti-oxidants [86] which cure respiratory and allergic diseases [94]. Yellow onions contain good amount of dietary fibers that cut down risk of lipid storage diseases and protects from stomach infection [96]. [95, 96] and increase antioxidant plasma status in humans [97]. Onion flesh and onion peel enhances antioxidant status in aged rats [98].

\section{Therapeutic Uses}

Therapeutically onion has multiple anti-disease potential against number of diseases. In the past it was traditionally used by ancient Greece athletes for lighten the balance of the blood [99]. Use of onions has good evidence from dead bodies preserved in Egyptian burials [100]. Traditionally, onions were prescribed to facilitate bowel movements and erections. These are good to relieve headaches, coughs, gastric problems and hair loss. The pungent juice of onions are used to repel insects mainly moths and houseflies repellent. These are also used to make into syrups, to form poultices, and rubbed on the skin to prevent insect bites. When chopped onion buds flutter certain chemical substances which irritate the eyes and show. They are pungent smell. Dried onion bulbs release eye irritant during chopping. Chopping of onion bulbs causes damage to cells which allows enzymes called alliinases to break down amino acid sulfoxides and generate sulfenic acids. A specific sulfenic acid, 1propenesulfenic acid, is rapidly acted on by a second enzyme, the lachrymatory factor synthase (LFS), giving syn-propanethial-S-oxide, a volatile gas known as the onion lachrymatory factor or LF that generates fast tears in exposed onion person 101. Onions are traditionally used in preparation of Ayurvedic formulations for wound healing [102] and in treating cardiovascular diseases, hyperglycemia, and stomach cancer. Its topical preparations have been used for prevention of surgical scars. Clinically on average daily doses of $50 \mathrm{~g}$ of fresh onion, $50 \mathrm{~g}$ of fresh onion juice, or $20 \mathrm{~g}$ of dried onion have been suggested good for health. Topical onion extract gels are used in scarring and are generally applied 3 times daily. It is used for prevention of presternal hypertrophic scar protection [103]. Allium cepa (dry bulbs) showed antimicrobial activity against Gram positive and Gram negative bacteria and fungi in vitro tests [104]. Onion aqueous extract shows antioxidant and hepatoprotective activity.

Onion (Allium cepa L.) is widely used in the food industry for its nutritional and aromatic properties. Onion contains active components, which possess antioxidant, cytotoxic and pro-apoptotic properties. Inclusion of fresh green onions in the diet can influence the initiation and the progression of carcinogenesis, as it acts on pathways implied in cell proliferation, apoptosis and metastasis. Consumption of large amounts of Allium vegetables reduces risk for gastric [105] and prostate cancer [106]. Food-derived flavonoid quercetin, widely distributed in onions is able to inhibit growth of various cancer cells. It can be considered as a good candidate for anticancer therapy. It behaves as an antioxidant and/or prooxidant as well as modulating different intracellular signaling cascades may all play a certain role [107]. Combining onion and grape resulted in a synergistic anti-proliferative effect (APE) against MCF-7 compared with either onion or grape treatment alone [108]. Allium cepa Linn is commonly used as supplementary folk remedy for cancer therapy. Polyphenols extracted from lyophilized $A$. cepa Linn (PEAL) were found effective in human leukemia cells 
and their mechanisms. PEAL inhibited cancer cell growth by inducing caspase-dependent apoptosis [49, 109]. Excessive consumption of garlic is harmful as it toxic at a certain limits; it is one of the most important modifiable risk factors. Major dietary factors now known to promote cancer development are polished grain foods and low intake of fresh vegetables, with general importance for an unhealthy lifestyle and obesity [110].

Quercetin is a member of the flavonoid family shows variety of anti-cancer activities. It shows antiproliferation, cell cycle arrest, and induction of apoptosis of cancer cells. Quercetin has also been shown to undergo oxidation [111]. DATS a natural product isolated from onion and garlic shows alteration in carcinogen-metabolizing enzymes, cell cycle arrest, induction of apoptotic cell death, suppression of oncogenic signal transduction pathways, and inhibition of neoangiogenesis [112]. Quercetin, found in onions is associated with the down-regulation of PKC and RhoA by blocking MAPK and PI3K/AKT signaling pathways and NF-KB and UPA, resulting in inhibition of MMP-2 and MMP-9 signaling [112]. It shows inhibition of migration and invasion of SAS cells. Dihydroquercetin (taxifolin) is a potent flavonoid found in onions. It does activation of the antioxidant response element (ARE) and detoxifying phase II enzymes, and causes inhibition of cytochrome $\mathrm{P}(450)$ and fatty acid synthase in carcinogenesis. It increases TNF- $\alpha$ and NF-K $\beta$ dependent transcription in hepatitis $C$ infections. It also shows scavenging effect of myeloperoxidase (MPO) derived reactive nitrogen species and subsequent effects on cholesterol biosynthesis as well as the effects on apob/apoA-I, HMG-CoA reductase and apoptosis and contains high therapeutic potential [113]. Ethyl acetate extract of onion (EEO) shows potent inhibitory effects on animal fatty acid synthase (FAS), that could induce apoptosis in FAS over-expressing human breast cancer MDA-MB-231 cells [114].

\section{Phytochemistry}

Onions contain $89 \%$ water, $1.5 \%$ protein, and vitamins $\mathrm{B} 1, \mathrm{~B} 2$, and $\mathrm{C}$, along with potassium and selenium. Onions also possess important polysaccharides such as fructosans, saccharose, peptides, flavonoids (mostly quercetin) and essential oil. Onion contains numerous sulfur compounds, including thiosulfinates and thiosulfonates; cepaenes; S-oxides; S,S-dioxides; mono-, di-, and tri-sulfides; and sulfoxides. Mincing or crushing the bulb releases cysteine sulfoxide from cellular compartments, making contact with the enzyme alliinase from the adjacent vacuoles. Upon hydrolysis it releases reactive intermediate sulfenic acid compounds and then to the various sulfur compounds. Onions contain phytochemical compounds such as phenolics and flavonoids that basic research shows to have potential anti-inflammatory,anti-cholesterol, anticancer and antioxidant properties [115]. These include quercetin and its glycosides quercetin 3,4'-diglucoside andquercetin-4'-glucoside [116, 117] (Table 4).

Red onions have considerable content of anthocyanin pigments, with high percentage of flavonoid content [118]. Onion flavonoids showed chemopreventive effect and are used in treatment of cardiovascular diseases and stop heartburn [119,120] (Table 4). Allium cepa red and white varieties showed anti-oxidant activities [121]. Quercetin-3'-O-beta-Dglucoside isolated from Allium cepa antioxidant activities [122]. Certain onion genotypes containing higher contents of sulfur in the bulb showed greater antiplatelet activity. Thiosulfinates dimethyl- and diphenyl-thiosulfinate slow down thrombocyte biosynthesis. Similarly, S-methyl cysteine sulfoxide (Figure 1) isolated from onions (Allium cepa Linn) shows antioxidant effects in alloxan diabetic rats [123]. Dietary flavonols protect diabetic human lymphocytes against oxidative damage to DNA [124].

\section{Other Allium species}

Fresh bulb contains organic sulfur compounds including $0.2 \%$ trans-S-(1-propenyl) cysteine sulfoxide, alliin (S-allyl-L cysteine sulfpxide), S-methyl-cysteine sulfoxide (Methylliin), S-propylcysteine sulfoxide (propylalliin) which are converted to simpler unstable sulfur compounds by the enzyme allinase present when onion is cut or crushed. Flavor compound s- allyl propenyl or propyl disulfides and trisulfides are major constituents found in Allium species. Smaller amounts of tetra sulfides, monosulfides, thiols, thiophenes are also found in Allium. Main bio-organic constituents found in Allium porum di are propyl disulphide and methyl propyl sulfide. Dimethyl suphifide methyl propyltrisulphide, $\quad 2, \quad 5, \quad$ dihydro-3,4-dimethylthiophen,allyl methyl sulphide and various thiophanes are also found. Fresh bulbs contain sapogenins, porigenins $A$ and $B$, neoporigenins, neoagigenin which show strong biological activity. A new steroidal saponin was isolated from the bulbs of Allium ampeloprasum var. porrum which exhibit significant antiinflammatory and antiulcerogenic properties (Table 4).

\section{Shallot}

The shallot is a type of onion, specifically a botanical variety of of the species Allium cepa [125]. In 
India shallot it is recognized by several other names i.e. kaanda or gandana in Maharashtra, cheriya ulli in Malyalam, ulli piaja in Odia, chinna ullipayi (Telgu). In the Kashmiri language, shallots are called praan. In Nepal it is known as chyapi The shallot was formerly classified as a separate species, $A$. ascalonicum Shallots (wild garlic/Osghordion) with the scientific name of Allium hertifolium, is one of the most famous plants from the Alliaceae family. These are used after slicing and deep fry as condiment in Asian cuisine. These are used in fresh cooking and mixed in pickle preparation. Crispy shallot chips are also used in southern Chinese cuisine. Shallots is also used for scallion in few countries. French gray shallot or grisailles (Allium oschaninii), a species referred to as true shallot. In Iran shallots are also used to make different types of torshi . In Nepal, shallots are used as one of the ingredients for making momo. In Kashmir shallots are widely used in preparation of Wazwan Kashmiri cuisine, as they add distinct flavor and prevent curry from getting black which is a common problem with onions. In India it is used as a home remedy for sore throats, mixed with jaggery or sugar. The active ingredients of the plant could be referred to agapentagenin, allicin, omega-3, omega-6, and minerals such as potassium, sodium, magnesium, iron, copper, zinc, and manganese [126]. Shallots are rich in fatty acids and minerals with many pharmacological effects such as its effect on the respiratory and nervous system and blood dilution, as reflected in the modern medicine. Shallots are traditional medicine which show anti-warts, anti-lipoma, anti-kidney stone, and its diuretic effects [126]. Shallots contain flavonoids and phenols and show mild flavor and have similar taste onions. When sliced these also release substances which irritate eyes and induce tearing. . In addition to $A$. sativum, these compounds are also present in $A$. hirtifolium (shallot) and have been used to treat various diseases [127]. Therapeutic uses and pharmacological properties of garlic, shallot, and their biologically active compounds [127]. Effect of hydroalcoholic extract of Allium hirtifolium (Persian shallot) on the level of liver enzymes in streptozotocin (STZ)-induced diabetic rats. Hepatoprotective effects of hydroalcoholic extract of Allium hirtifolium (Persian shallot) in diabetic rats [128]. Antioxidant micronutrients in the extract of Persian shallot may rehabilitate liver damages caused by free radicals in diabetic rats. Liver-protective effects of hydroalcoholic extract of Allium hirtifolium boiss. In alloxan-induced diabetes mellitus rats hydroalcoholic extract of shallot significantly decrease serum contents of liver enzymes (ALP, AST, and ALT) in treated groups [129]. Allium hirtifolium Boiss flowers contain six furostanol and spirostanol saponins, alliogenin 3- Obeta-D-glucopyranoside, gitogenin 3- O-beta-Dglucopyranosyl-(1-->4)- O-beta-D-glucopyranoside, and agapanthagenin 3- O-beta-D-glucopyranoside. Shaloots also contain high amount of flavonol glycosides kaempferol 3- O-beta-D-rhamnopyranosyl(1-->2)-glucopyranoside, kaempferol 3- O-beta-Dglucopyranosyl-(1-->4)-glucopyranoside, kaempferol 3O-glucopyranoside, kaempferol 7-O-glucopyranoside in flowers and bulbs [130]. In a meta-analysis, consumption of high levels of Allium vegetables reduced the risk for gastric cancer risk [131]. Garlic and shallots are safe and rich sources of biologically active compounds with low toxicity from Persian shallot (Allium stipitatum) [132]. hydroalcoholic extract of Persian shallot significantly decreased serum levels of FBS and $\mathrm{HbA} 1 \mathrm{c}$ in treated groups (in a dose dependent manner) $(p<0.05)$. Dietary intake of Allium could be beneficial for prevention of cardiovascular diseases. Allium species such as Allium ampeloprasum, A. hirtifolium, A. haemanthoides, $A$. vavillovi, $A$. atroviolaceum, $A$. jesdianum, $A$. shelkovnikovii) using arachidonic acid (AA) and adenosine diphosphate (ADP) were found platelet aggregation inducers [133]. Allium hirtifolium aqueous extract show anti-dermatophyte activities against Trichophyton rubrum, Trichophyton mentagrophytes, Microsporum canis, M. gypseum, Trichophyton schoenleinii and Trichophyton verrucosum var. album [134]. Allium vegetables show antiinflammatory and neurological activity and protective effect against breast cancer [135]. Green raw Allium vegetables, particularly garlic and leek, reduce the risk of breast cancer, while high consumption of cooked onion may be associated with an increased risk of breast cancer. Nutraceuticals from Allium vegetables show strong anti-inflammatory, anti-oxidant, anti-tumorigenic, anti-invasive, antiangiogenic, anti-diabetic, neuroprotective, and cardioprotective effects [136].

\section{Chives}

Chives are the common name of Allium schoenoprasum an edible species of the Allium genus [137]. Chives possess insect-repelling properties and used for controlling gardens pests. A chive is a perennial plant found in Europe, Asia, and North America. Chives are a commonly used herb and can be found in grocery stores or grown in home gardens. In culinary use, the scapes and the unopened, immature flower buds are diced and used as an ingredient for fish, potatoes, soups, and other dishes. 
Chives are grown for their scapes which are used for culinary purposes as a flavoring herb, and provide a somewhat milder flavor than those of other Allium species. Chives have a wide variety of culinary uses, such as in traditional dishes in many countries. The medicinal properties of chives are similar to those of garlic, but weaker; the faint effects in comparison with garlic are probably the main reason for their limited use as a medicinal herb. Containing numerous organosulfur compounds such as allyl sulfides [138] and alkyl sulfoxides, chives are reported to have a beneficial effect on the circulatory system. They also have mild stimulant, diuretic and antiseptic properties [139]. As chives are usually served in small amounts and never as the main dish, negative effects are rarely encountered, although digestive problems may occur following over consumption. Chives are also rich in vitamin $\mathrm{C}$ and $\mathrm{A}$ contains trace amounts of sulfur, and are rich in calcium and iron.

\section{LEEKS}

The leek is a vegetable a cultivar of Allium ampeloprasum vegetable (Table 1). The edible portions of the leek are the white base of the leaves light green parts, bundle of leaf sheaths are edible. Leeks are recognized by different names but all are cultivars of $A$. ampeloprasum [140]. It's green vegetable is crunchy and firm with a mild, onion-like taste. Boiling turns it soft and mild in taste. Raw leeks can be used in salads and for adding flavor to stock [141]. Leaves in group tied with twine and other herbs are used to form a bouquet garni. Leeks are typically chopped into slices 5-10 $\mathrm{mm}$ thick. The slices have a tendency to fall apart, due to the layered structure of the leek. The Leeks are an ingredient of cock-a-leekie soup, leek and potato soup, and vichyssoise, as well as plain leek soup. Regular use of leaks in salads slightly increases T3 level but the T4 serum level was declined [142].

Scallion, Green Onion, Spring Onion and Salad Onion are various Allium species which are used as raw or cooked as vegetable. These are characterized by hollow green leaves but these are used while they lack a fully developed root bulb. Scallions have a milder taste than most onions. Diced scallions are used in soup, noodle and seafood dishes, as well as sandwiches, curries or as part of a stir fry. In south USA scallions are sprinkled with salt and grilled whole to add flavor and taste to cheese and rice. In Japan both leaf green scallions and root green scallions are popular and are used as additive for green vegetables. But green portion or thick white portions of the scallion are consumed. In Japanese cuisine, scallions are used in abundance, as an accompaniment to tofu, noodle dishes, hot pots, and stir fries. Welsh onion is used to prepare dura hành in Vietnam. In India it is eaten as an appetizer (raw) with main meals. In north India Coriander, Mint and Onion Chutney is made using scallions (raw). Spring onions may be cooked or used raw as a part of salads in many recipes.

\section{CONCLUSION}

Allium vegetables are a good source of various nutraceuticals and are widely used in the food industry because of its aromatic properties. Inclusion of fresh green onions in the diet inhibits initiation and the progression of carcinogenesis. Food-derived flavonoid quercetin inhibits growth of various cancer cells and considered best candidate for anticancer therapy. It shows anti-proliferation, cell cycle arrest, and induction of apoptosis in cancer cells. Quercetin does downregulation of PKC and RhoA by blocking MAPK and PI3K/AKT signaling pathways and NF-KB and UPA, resulting in inhibition of MMP-2 and MMP-9 signaling. Onions contain phenolics and falvonoids that have potential anti-inflammatory, anti-cholesterol activity, anticancer and antioxidant properties. Dihydroquercetin (taxifolin) is a potent flavonoid does activation of the antioxidant response element (ARE) and detoxifying phase II enzymes, and causes inhibition of cytochrome $P(450)$ and fatty acid synthase in carcinogenesis. It increases TNF- $\alpha$ and NF-K $\beta$ dependent transcription in hepatitis $C$ infections. DATS is another natural product isolated from onion and garlic shows alteration in carcinogen-metabolizing enzymes, cell cycle arrest, induction of apoptotic cell death, suppression of oncogenic signal transduction pathways, and inhibition of neoangiogenesis. Allium vegetable also contain polyphenols that stops proliferation of leukemia cells and inhibit major signaling pathways implied in cell proliferation, apoptosis and metastasis. Green onions are best dietary supplements as they contain many active components which possess broad spectrum biological activity that can be used in therapeutics of number of human diseases. All current researches justified allium compounds and extracts as strong cardioprotective, hypolipidemic, antioxidative and antiinflammatory agents. Allium natural compounds are highly beneficial in atherosclerosis prevention and treatment are strong supplementary folk remedy for cancer therapy. These are curative and provide longevity. But for preparation of many more allium based formulations new combinations be needed to have a single composite drug for various treatments. It will need further investigation in this field. 


\section{ABBREVIATIONS AND ACRONYMS}

$$
\begin{aligned}
& \text { DATS }=\text { Diallyl trisulphide } \\
& \text { DADS }=\text { diallyl disulfide } \\
& \text { SAMC }=\text { S-allylmercaptocysteine } \\
& \text { AGE }=\text { age garlic extract } \\
& \text { SAC }=\text { S-allylcysteine } \\
& \text { CRC }=\text { colorectal cancer (CRC) } \\
& \text { LDL }=\text { Low density lipoproteins } \\
& \text { LFS }=\text { lachrymatory factor synthase }
\end{aligned}
$$

\section{REFERENCES}

[1] Sengupta A, et al. Allium vegetables in cancer prevention: an overview 2004; 5(3): 237-45.

[2] Rocio MC, Rion JL. A review of some antimicrobial substances isolated from medicinal plants reported in the literature review of phytochemical analysis on garlic 1978 1972. Phytother Rev 1982; 3: 117-25.

[3] Alli JA, et al. In-vitro assessments of the effects of garlic (Allium sativum) extract on clinical isolates of Pseudomonas aeruginosa and Staphylococcus aureus. Adv Appl Sci Res 20112; 2: 25-36.

[4] Chu YL, et al. Autophagy therapeutic potential of garlic in human cancer therapy. J Tradit Complement Med 2013; 3: 159-62.

https://doi.org/10.4103/2225-4110.114895

[5] Block E. The chemistry of garlic and onions. Sci Am 1985; 252: 114-9

https://doi.org/10.1038/scientificamerican0385-114

[6] Sultan MT, et al. Immunity: Plants as effective mediators. Crit Rev Food Sci Nutr 2014; 54: 1298-308. https://doi.org/10.1080/10408398.2011.633249

[7] Butt MS, et al. Garlic: Nature's protection against physiological threats. Crit Rev Food Sci Nutr 2009; 49: 53851.

https://doi.org/10.1080/10408390802145344

[8] Hahm ER, Singh SV. Diallyl trisulfide inhibits estrogen receptor- $\alpha$ activity in human breast cancer cells. Breast Cancer Res Treat 2014; 144: 47-57. https://doi.org/10.1007/s10549-014-2841-x

[9] Quintero-Fabián $\mathrm{S}$, et al. Alliin, a garlic (Allium sativum) compound, prevents LPS-induced inflammation in 3T3-L1 adipocytes. Mediators Inflamm 2013; 2013: 381815. https://doi.org/10.1155/2013/381815

[10] Khuda-Bukhsh AR, et al. Molecular approaches toward targeted cancer prevention with some food plants and their products: Inflammatory and other signal pathways. Nutr Cancer 2014; 66: 194-205. https://doi.org/10.1080/01635581.2014.864420

[11] Xu YS, et al. S-allylcysteine, a garlic derivative, suppresses proliferation and induces apoptosis in human ovarian cancer cells in vitro. Acta Pharmacol Sin 2014; 35: 267-74.

https://doi.org/10.1038/aps.2013.176

[12] Shin DY, et al. Inhibiting invasion into human bladder carcinoma 5637 cells with diallyl trisulfide by inhibiting matrix metalloproteinase activities and tightening tight junctions. Int J Mol Sci 2013; 14: 19911-22.

https://doi.org/10.3390/ijms141019911
[13]

Borkowska A, et al. Diallyl trisulfide is more cytotoxic to prostate cancer cells $\mathrm{PC}-3$ than to noncancerous epithelial cell line PNT1A: A possible role of p66Shc signaling axis. Nutr Cancer 2013; 65: 711-7.

https://doi.org/10.1080/01635581.2013.789115

[14] Zhang CL, et al. Garlic oil attenuated nitrosodiethylamineinduced hepatocarcinogenesis by modulating the metabolic activation and detoxification enzymes. Int J Biol Sci 2013; 9: 237-45.

https://doi.org/10.7150/ijbs.5549

[15] Gail $\mathrm{MH}$, et al. Garlic, vitamin, and antibiotic treatment for Helicobacter pylori: A randomized factorial controlled trial. Helicobacter 2007; 12: 575-8. https://doi.org/10.1111/j.1523-5378.2007.00528.x

[16] Zhang YK, et al. A proteomic study on a human osteosarcoma cell line Saos-2 treated with diallyl trisulfide. Anticancer Drugs 2009; 20: 702-12. https://doi.org/10.1097/CAD.0b013e32832e89c7

[17] Fenwick GR, Hanley AB. Allium species poisoning. Vet Rec 1985; 516: 28. https://doi.org/10.1136/vr.116.1.28

[18] Yun HM, et al. Potential therapeutic effects of functionally active compounds isolated from garlic. Pharmacol Ther 2014; 142: 183-95.

https://doi.org/10.1016/j.pharmthera.2013.12.005

[19] Williams FM, et al. Dietary garlic and hip osteoarthritis: Evidence of a protective effect and putative mechanism of action. BMC Musculoskelet Disord 2010; 11: 280. https://doi.org/10.1186/1471-2474-11-280

[20] Dugo $M$, et al. Herbal remedies: Nephrotoxicity and drug interactions. G Ital Nefrol 2010; 27 Suppl 52: S5-9.

[21] Zhou XF, et al. Allium vegetables and risk of prostate cancer: Evidence from 132,192 subjects. Asian Pac J Cancer Prev 2013; 14: 4131-4.

https://doi.org/10.7314/APJCP.2013.14.7.4131

[22] Zhu B, et al. Allium vegetables and garlic supplements do not reduce risk of colorectal cancer, based on meta-analysis of prospective studies. Clin Gastroenterol Hepatol 2014; 12: 1991-2001.e1-4.

[23] Lee J, et al. HPLC-MTT assay: Anticancer activity of aqueous garlic extract is from allicin. Anal Biochem 2013; 436: 187-9. https://doi.org/10.1016/j.ab.2013.01.033

[24] Tapiero $\mathrm{H}$, et al. Organosulfur compounds from alliaceae in the prevention of human pathologies. Biomed Pharmacother 2004; 58: 183-93. https://doi.org/10.1016/j.biopha.2004.01.004

[25] Blumenthal M. Herb Sales Down 7.4 Percent in Mainstream Market. Herbal Gram. Austin, Texas: American Botanical Council; 2005. p. 63

[26] Aviello G, et al. Garlic: Empiricism or science? Nat Prod Commun 2009; 4: 1785-96.

[27] Berginc K, Kristl A. The mechanisms responsible for garlic drug interactions and their in vivo relevance. Curr Drug Metab 2013; 14: 90-101.

\section{https://doi.org/10.2174/138920013804545188}

[28] Sabater-Molina M, et al. Dietary fructooligosaccharides and potential benefits on health. J Physiol Biochem 2009; 65: 315-28. https://doi.org/10.1007/BF03180584

[29] Khatua TN, et al. Garlic and cardioprotection: Insights into the molecular mechanisms. Can J Physiol Pharmacol 2013; 91: 448-58. https://doi.org/10.1139/cjpp-2012-0315

[30] Keys A. Wine, garlic, and CHD in seven countries. Lancet 1980; 1: $145-6$ https://doi.org/10.1016/S0140-6736(80)90620-0 
[31] Campbell JH, et al. Molecular basis by which garlic suppresses atherosclerosis. J Nutr 2001; 131: 1006S-9.

[32] Koscielny $\mathrm{J}$, et al. The antiatherosclerotic effect of Allium sativum. Atherosclerosis 1999; 144: 237-49. https://doi.org/10.1016/S0021-9150(99)00060-X

[33] Sendl A, et al. Comparative pharmacological investigations of Allium ursinum and Allium sativum. Planta Med 1992; 58: 1-7. https://doi.org/10.1055/s-2006-961378

[34] Ali M. Mechanism by which garlic (Allium sativum) inhibits cyclooxygenase activity. Effect of raw versus boiled garlic extract on the synthesis of prostanoids. Prostaglandins Leukot Essent Fatty Acids 1995; 53: 397-400. https://doi.org/10.1016/0952-3278(95)90102-7

[35] Arunkumar R, et al. Effect of diallyl disulfide on insulin-like growth factor signaling molecules involved in cell survival and proliferation of human prostate cancer cells in vitro and in silico approach through docking analysis. Phytomedicine 2012; 19: 912-23. https://doi.org/10.1016/j.phymed.2012.04.009

[36] Chi MS. Effects of garlic products on lipid metabolism in cholesterol-fed rats (41494). Proc Soc Exp Biol Med 1982; 171: 174-8.

https://doi.org/10.3181/00379727-171-41494

[37] Chi MS, et al. Effects of garlic on lipid metabolism in rats fed cholesterol or lard. J Nutr 1982; 112: 241-8.

https://doi.org/10.1007/BF02537229

[38] Qureshi AA, et al. Inhibition of cholesterol and fatty acid biosynthesis in liver enzymes and chicken hepatocytes by polar fractions of garlic. Lipids 1983; 18: 343-8. https://doi.org/10.1016/0021-9150(87)90235-8

[39] Qureshi AA, et al. Influence of minor plant constituents on porcine hepatic lipid metabolism. Impact on serum lipids. Atherosclerosis 1987; 64: 109-15.

[40] Gebhardt R, et al. Inhibition of cholesterol biosynthesis by allicin and ajoene in rat hepatocytes and HepG2 cells. Biochim Biophys Acta 1994; 1213: 57-62. https://doi.org/10.1016/0005-2760(94)90222-4

[41] Yeh YY, Yeh SM. Garlic reduces plasma lipids by inhibiting hepatic cholesterol and triacylglycerol synthesis. Lipids 1994; 29: 189-93.

https://doi.org/10.1007/BF02536728

[42] Gupta N, Porter TD. Garlic and garlic-derived compounds inhibit human squalene monooxygenase. J Nutr 2001; 131: 1662-7.

[43] Yeh YY, Liu L. Cholesterol-lowering effect of garlic extracts and organosulfur compounds: Human and animal studies. J Nutr 2001; 131(3s): 989S-93S.

[44] Gebhardt R, Beck H. Differential inhibitory effects of garlicderived organosulfur compounds on cholesterol biosynthesis in primary rat hepatocyte cultures. Lipids 1996; 31: 1269-76. https://doi.org/10.1007/BF02587912

[45] Liu L, Yeh YY. Inhibition of cholesterol biosynthesis by organosulfur compounds derived from garlic. Lipids 2000; 35 : 197-203. https://doi.org/10.1007/BF02664770

[46] Bordia A, et al. Effect of garlic (Allium sativum) on blood lipids, blood sugar, fibrinogen and fibrinolytic activity in patients with coronary artery disease. Prostaglandins Leukot Essent Fatty Acids 1998; 58: 257-63. https://doi.org/10.1016/S0952-3278(98)90034-5

[47] Bordia A, Bansal HC. Letter: Essential oil of garlic in prevention of atherosclerosis. Lancet 1973; 2: 1491-2. https://doi.org/10.1016/S0140-6736(73)92750-5

[48] Dasgupta P, Bandyopadhyay SS. Role of di-allyl disulfide, a garlic component in NF-?B mediated transient G2-M phase arrest and apoptosis in human leukemic cell-lines. Nutr Cancer 2013; 65: 611-22.

https://doi.org/10.1080/01635581.2013.776090
[49] Ferri N, et al. Ajoene, a garlic compound, inhibits protein prenylation and arterial smooth muscle cell proliferation. $\mathrm{Br} \mathrm{J}$ Pharmacol 2003; 138: 811-8. https://doi.org/10.1038/sj.bjp.0705126

[50] Chan KC, et al. Protective effect of three diallyl sulphides against glucose-induced erythrocyte and platelet oxidation, and ADP-induced platelet aggregation. Thromb Res 2002; 108: 317-22. https://doi.org/10.1016/S0049-3848(03)00106-3

[51] Lawson LD, et al. Inhibition of whole blood plateletaggregation by compounds in garlic clove extracts and commercial garlic products. Thromb Res 1992; 65: 141-56. https://doi.org/10.1016/0049-3848(92)90234-2

[52] Keiss HP, et al. Garlic (Allium sativum L.) modulates cytokine expression in lipopolysaccharide-activated human blood thereby inhibiting NF-kappaB activity. J Nutr 2003; 133 2171-5.

[53] Blake GJ, Ridker PM. C-reactive protein and other inflammatory risk markers in acute coronary syndromes. $J$ Am Coll Cardiol 2003; 414 Suppl S: 37S-42.

[54] Ali M, et al. Garlic and onions: Their effect on eicosanoid metabolism and its clinical relevance. Prostaglandins Leukot Essent Fatty Acids 2000; 62: 55-73. https://doi.org/10.1054/plef.1999.0124

[55] Liu L, Yeh YY. S-alk(en)yl cysteines of garlic inhibit cholesterol synthesis by deactivating HMG-CoA reductase in cultured rat hepatocytes. J Nutr 2002; 132: 1129-34.

[56] Hedin U, et al. Control of smooth muscle cell proliferation in vascular disease. Curr Opin Lipidol 2004; 15: 559-65. https://doi.org/10.1097/00041433-200410000-00010

[57] Banerjee SK, et al. Garlic as an antioxidant: The good, the bad and the ugly. Phytother Res 2003; 17: 97-106. https://doi.org/10.1002/ptr.1281

[58] Dhawan V, Jain S. Effect of garlic supplementation on oxidized low density lipoproteins and lipid peroxidation in patients of essential hypertension. Mol Cell Biochem 2004; 266: 109-15.

https://doi.org/10.1023/B:MCBI.0000049146.89059.53

[59] Munday R, Munday CM. Low doses of diallyl disulfide, a compound derived from garlic, increase tissue activities of quinone reductase and glutathione transferase in the gastrointestinal tract of the rat. Nutr Cancer 1999; 34: 42-8. https://doi.org/10.1207/S15327914NC340106

[60] Stewart ZA, Westfall MD, Pietenpol JA. Cell-cycle dysregulation and anticancer therapy. Trends Pharmacol Sci 2003; 24: 139-45. https://doi.org/10.1016/S0165-6147(03)00026-9

[61] Kantor ED, et al. Association between use of specialty dietary supplements and C-reactive protein concentrations. Am J Epidemiol 2012; 176: 1002-13. https://doi.org/10.1093/aje/kws186

[62] Stanger MJ, et al. Anticoagulant activity of select dietary supplements. Nutr Rev 2012; 70: 107-17. https://doi.org/10.1111/j.1753-4887.2011.00444.x

[63] Brewster, James L. (1994). Onions and other vegetable Alliums (1st ed.). Wallingford, UK: CAB International. p. 16.

[64] All about onions, National Onion Association. Retrieved 2013-03-24.Allium cepa L. USDA, NRCS 2007. The PLANTS Database (http: //plants.usda.gov , July 2010). National Plant Data Center, Baton Rouge, LA 70874-4490 USA.

[65] Ministry of Agriculture, Fisheries and Food (1968). Home Preservation of Fruit and Vegetables. HMSO. p. 107.

[66] Mower, Chris. The difference between Yellow, White and red Onions. The Cooking Dish. Retrieved 2013-03-24.

[67] Wang $Y$, et al. Inhibitory effects of onion (Allium cepa L.) extract on proliferation of cancer cells and adipocytes via 
inhibiting fatty acid synthase. Asian Pac J Cancer Prev 2012; 13(11): 5573-9.

https://doi.org/10.7314/APJCP.2012.13.11.5573

[68] Mitra J, et al. Onion dehydration: a review. J Food Sci Technol 2012; 49(3): 267-77.

https://doi.org/10.1007/s13197-011-0369-1

[69] Weaver C, Marr ET. White vegetables: a forgotten source of nutrients: Purdue roundtable executive summary. Adv Nutr 2013 1; 4(3): 318S-26S.

[70] Ribeiro MA, et al. Zinc absorption in Brazilian subjects fed a healthy meal. J Hum Nutr Diet 2014 ; 2: 313-20.

[71] Gautam S, et al. Assessment of zinc deficiency and effect of dietary carrot, amchur and onion on zinc status during repletion in zinc-deficient rats. J Sci Food Agric 2012 Jan 15; 92(1): 165-70.

https://doi.org/10.1002/jsfa.4558

[72] Siracusa L, et al. Re-evaluation of traditional Mediterranean foods. The local landraces of 'Cipolla di Giarratana' (Allium cepa L.) and long-storage tomato(Lycopersicon esculentum L.): quality traits and polyphenol content. J Sci Food Agric 2013 Nov; 93(14): 3512-9.

https://doi.org/10.1002/jsfa.6199

[73] Abney KR, et al. UV-B radiation impacts shoot tissue pigment composition in Allium fistulosum L. cultigens. Scientific World Journal 2013; 31; 2013: 513867 .

[74] Jung JY, et al. Onion peel extracts ameliorate hyperglycemia and insulin resistance in high fat diet/streptozotocin-induced diabetic rats. Nutr Metab (Lond) 2011; 8(1): 18. https://doi.org/10.1186/1743-7075-8-18

[75] Inoue-Choi $\mathrm{M}$, et al. Reality check: there is no such thing as a miracle food. Nutr Cancer 2013; 65(2): 165-8. https://doi.org/10.1080/01635581.2013.748921

[76] Krishnaswamy K. Traditional Indian spices and their health significance. Asia Pac J Clin Nutr 2008; 17 Suppl 1: 265-8.

[77] Arai $\mathrm{Y}$, et al. Dietary intakes of flavonols, flavones and isoflavones by Japanese women and the inverse correlation between quercetin intake and plasma LDL cholesterol concentration. J Nutr 2000; 130(9): 2243-50.

[78] Myhre $\mathrm{R}$, et al. Intakes of garlic and dried fruits are associated with lower risk of spontaneous preterm delivery. $\mathrm{J}$ Nutr 2013; 143(7): 1100-8.

https://doi.org/10.3945/jn.112.173229

[79] Griffiths G, et al. Onions-a global benefit to health. Phytother Res 2002; 16(7): 603-615. https://doi.org/10.1002/ptr.1222

[80] Anderson $\mathrm{GH}$, et al. White vegetables: glycemia and satiety. Adv Nutr 2013; 4(3): 356S-67S.

https://doi.org/10.3945/an.112.003509

[81] Herrera A, et al. The effect of preparation of cebiche on the survival of enterotoxigenic Escherichia coli, Aeromonas hydrophila, and Vibrio parahaemolyticus. J Travel Med 2010; 17(6): 395-9.

https://doi.org/10.1111/j.1708-8305.2010.00465.x

[82] Wang $\mathrm{H}$, et al. Modified method for rapid quantitation of $\mathrm{S}-$ alk(en)yl-L-cysteine sulfoxide in yellow onions (Allium cepa L.). J Agric Food Chem 2007; 55(14): 5429-35.

https://doi.org/10.1021/jf070298d

[83] Cooper RG, Chifamba J. The nutritional intake of undergraduates at the University of Zimbabwe College of Health Sciences. Tanzan J Health Res 2009; 11(1): 35-9. https://doi.org/10.4314/thrb.v11i1.43249

[84] Wang $\mathrm{H}$, et al. Modified method for rapid quantitation of $\mathrm{S}$ alk(en)yl-L-cysteine sulfoxide in yellow onions (Allium cepa L.). J Agric Food Chem 2007; 55(14): 5429-35. https://doi.org/10.1021/jf070298d

[85] Winning $\mathrm{H}$, et al. An exploratory NMR nutri-metabonomic investigation reveals dimethyl sulfone as a dietary biomarker for onion intake. Analyst 2009; 134(11): 2344-51. https://doi.org/10.1039/b918259d
[86] Pellegrini N, et al. Effect of domestic cooking methods on the total antioxidant capacity of vegetables. Int J Food Sci Nutr 2009; 60 Suppl 2: 12-22. https://doi.org/10.1080/09637480802175212

[87] Owsikowski $\mathrm{M}$, et al. Antioxidants content in selected conventionally and organically cultivated vegetables. Rocz Panstw Zakl Hig 2008; 59(2): 223-30.

[88] Horiuchi $J$, et al. New vinegar production from onions. $J$ Biosci Bioeng 1999; 88(1): 107-9. https://doi.org/10.1016/S1389-1723(99)80186-8

[89] Tang $\mathrm{CH}$, et al. Water solution of onion crude powder inhibits RANKL-induced osteoclastogenesis through ERK, p38 and NF-kappaB pathways. Osteoporos Int 2009 Jan; 20(1): 93103.

https://doi.org/10.1007/s00198-008-0630-2

[90] Hoensch HP, Kirch W. Potential role of flavonoids in the prevention of intestinal neoplasia: a review of their mode of action and their clinical perspectives. Int J Gastrointest Cancer 2005; 35(3): 187-95.

https://doi.org/10.1385/IJGC:35:3:187

[91] Infante HG, et al. Current mass spectrometry strategies for selenium speciation in dietary sources of high-selenium. Anal Bioanal Chem 2005; 382(4): 957-67. https://doi.org/10.1007/s00216-005-3177-5

[92] Yang J, et al. Varietal differences in phenolic content and antioxidant and antiproliferative activities of onions. J Agric Food Chem 2004 Nov 3; 52(22): 6787-93. https://doi.org/10.1021/jf0307144

[93] Bornet FR, et al. Nutritional aspects of short-chain fructooligosaccharides: natural occurrence, chemistry, physiology and health implications. Dig Liver Dis 2002; 34 Suppl 2: S111-20. https://doi.org/10.1016/S1590-8658(02)80177-3

[94] Jaber R. Respiratory and allergic diseases: from upper respiratory tract infections to asthma. Prim Care $2002 ; 29(2)$ : 231-61. https://doi.org/10.1016/S0095-4543(01)00008-2

[95] Floruta CV. Dietary choices of people with ostomies. J Wound Ostomy Continence Nurs 2001; 28(1): 28-31.

[96] Marlett JA, Marlett JA. Changes in content and composition of dietary fiber in yellow onions and red delicious apples during commercial storage. J AOAC Int 2000; 83(4): 992-6.

[97] Di Renzo L, et al. Is antioxidant plasma status in humans a consequence of the antioxidant food content influence? Eur Rev Med Pharmacol Sci 2007; 11(3): 185-92.

[98] Park J, et al Onion flesh and onion peel enhance antioxidant status in aged rats. J Nutr Sci Vitaminol (Tokyo) 2007; 53(1): 21-9. https://doi.org/10.3177/jnsv.53.21

[99] About Onion HistoryRetrieved 2013-09-13

[100] Abdel-Maksouda, et al. (2011). A review on the materials used during the mummification process in ancient Egypt. Mediterranean Archaeology and Archaeometry 11 (2): 129150.

[101] Eric Block, Garlic and Other Alliums: The Lore and the Science (Cambridge: Royal Society of Chemistry, 2010.

[102] Gangopadhyay KS, et al. Pharmacological evaluation and chemical standardization of an Ayurvedic formulation for wound healing activity. Int J Low Extrem Wounds 2014; 13(1): 41-9. https://doi.org/10.1177/1534734614520705

[103] Jenwitheesuk K, et al. Role of silicone derivative plus onion extract gel in presternal hypertrophic scar protection: a prospective randomized, double blinded, controlled trial. Int Wound J 2012; 9(4): 397-402. https://doi.org/10.1111/j.1742-481X.2011.00898.x

[104] Bakht J, et al. In vitro antimicrobial activity of Allium cepa (dry bulbs) against Gram positive and Gram negative bacteria and fungi. Pak J Pharm Sci 2014; 27(1): 139-45. 
[105] Colli JL, Amling CL. Chemoprevention of prostate cancer: what can be recommended to patients? Curr Urol Rep 2009; 10(3): 165-71. https://doi.org/10.1007/s11934-009-0029-4

[106] Zhou XF, et al. Allium vegetables and risk of prostate cancer: evidence from 132,192 subjects. Asian Pac J Cancer Prev 2013; 14(7): 4131-4.

https://doi.org/10.7314/APJCP.2013.14.7.4131

[107] Sak K. Site-specific anticancer effects of dietary flavonoid quercetin. Nutr Cancer 2014; 66(2): 177-93. https://doi.org/10.1080/01635581.2014.864418

[108] Wang S, et al. Antioxidant capacity of food mixtures is not correlated with their antiproliferative activity against MCF-7 breast cancer cells. J Med Food 2013; 16(12): 1138-45. https://doi.org/10.1089/jmf.2013.0051

[109] Han $\mathrm{MH}$, et al. Polyphenols isolated from Allium cepa L. induces apoptosis by suppressing IAP-1 through inhibiting PI3K/Akt signaling pathways in human leukemic cells. Food Chem Toxicol 2013; 62: 382-9.

https://doi.org/10.1016/j.fct.2013.08.085

[110] Zeng YW, et al. Strategies of functional food for cancer prevention in human beings. Asian Pac J Cancer Prev 2013; 14(3): 1585-92.

https://doi.org/10.7314/APJCP.2013.14.3.1585

[111] Pham $A$, et al. Rapid dimerization of quercetin through an oxidative mechanism in the presence of serum albumin decreases its ability to induce cytotoxicity in MDA-MB-231 cells. Biochem Biophys Res Commun 2012; 427(2): 415-20. https://doi.org/10.1016/j.bbrc.2012.09.080

[112] Antony ML, Singh SV. Molecular mechanisms and targets of cancer chemoprevention by garlic-derived bioactive compound diallyl trisulfide. Indian J Exp Biol 2011; 49(11): 805-16. Review.

[113] Weidmann AE. Dihydroquercetin: More than just an impurity? Eur J Pharmacol 2012; 684(1-3): 19-26. https://doi.org/10.1016/j.ejphar.2012.03.035

[114] Wang $Y$, et al. Inhibitory effects of onion (Allium cepa L.) extract on proliferation of cancer cells and adipocytes via inhibiting fatty acid synthase. Asian Pac J Cancer Prev 2012; 13(11): 5573-9.

https://doi.org/10.7314/APJCP.2012.13.11.5573

[115] Yang J, et al. Varietal Differences in Phenolic Content and Antioxidant and Antiproliferative Activities of Onions. Journal of Agricultural and Food Chemistry 2004; 52 (22): 67876793.

https://doi.org/10.1021/jf0307144

[116] Slimestad R, et al. Onions: A source of unique dietary flavonoids. Journal of Agricultural and Food Chemistry 2007; 55 (25): 10067-80. https://doi.org/10.1021/jf0712503

[117] Williamson G, et al. Dietary quercetin glycosides: antioxidant activity and induction of the anticarcinogenic phase II marker enzyme quinone reductase in Hepalclc7 cells. Carcinogenesis 1997; 17 (11): 2385-2387. https://doi.org/10.1093/carcin/17.11.2385

[118] Olsson ME, et al. Quercetin and isorhamnetin in sweet and red cultivars of onion (Allium cepa L.) at harvest, after field curing, heat treatment, and storage. Journal of Agricultural Food Chemistry 2010; 58 (4): 2323-2330. https://doi.org/10.1021/jf9027014

[119] Majewska-Wierzbicka $M$, Czeczot $H$. Flavonoids in the prevention and treatment of cardiovascular diseases. Pol Merkur Lekarski 2012; 32(187): 50-4.

[120] Block E, et al. Onions and heartburn. Am J Gastroenterol 1992; 87(5): 679-80.

[121] Benmalek $Y$, et al. Anti-microbial and anti-oxidant activities of Illicium verum, Crataegus oxyacantha ssp monogyna and
Allium cepa red and white varieties. Bioengineered 2013; 4(4): 244-8.

https://doi.org/10.4161/bioe.24435

[122] Arung ET, et al. Melanin biosynthesis inhibitory and antioxidant activities of quercetin-3'-O-beta-D-glucoside isolated from Allium cepa. Z Naturforsch C 2011; 66(5-6): 209-14. https://doi.org/10.5560/ZNC.2011.66c0209

[123] Kumari K, Augusti KT. Antidiabetic and antioxidant effects of S-methyl cysteine sulfoxide isolated from onions (Allium cepa Linn) as compared to standard drugs in alloxan diabetic rats. Indian J Exp Biol 2002; 40(9): 1005-9.

[124] Lean ME, et al. Dietary flavonols protect diabetic human lymphocytes against oxidative damage to DNA. Diabetes 1999 ; 48(1): 176-81 https://doi.org/10.2337/diabetes.48.1.176

[125] Fritsch RM, Friesen N. Chapter 1: Evolution, Domestication, and Taxonomy. In H. D. Rabinowitch and L. Currah. Allium Crop Science: Recent Advances. Wallingford, UK: CABI ublishing 2002; p. 21.

[126] Abdehvand LZ, Soleymani S. A Comparative Study of Allium hirtifolium in Traditional and Modern Medicine. Iran J Med Sci. 2016; 41(3 Suppl): S16.

[127] Mikaili $P$, et al. Therapeutic uses and pharmacological properties of garlic, shallot, and their biologically active compounds. Iran J Basic Med Sci. 2013; 16(10): 1031-48.

[128] Javad $\mathrm{H}$, et al. Hepatoprotective effects of hydroalcoholic extract of Allium hirtifolium (Persian shallot) in diabetic rats. $\mathrm{J}$ Basic Clin Physiol Pharmacol 2012; 23(2): 83-7. https://doi.org/10.1515/jbcpp-2012-0017

[129] Kazemi S, et al. Liver-protective effects of hydroalcoholic extract of Allium hirtifolium boiss. In rats with alloxan-induced diabetes mellitus. ARYA Atheroscler. 2010; 6(1): 11-5.

[130] Barile E, et al. Structure-activity relationships for saponins from Allium hirtifolium and Allium elburzense and their antispasmodic activity. Planta Med 2005; 71(11): 1010-8. https://doi.org/10.1055/s-2005-873134

[131] Zhou $Y$, et al. Consumption of large amounts of Allium vegetables reduces risk for gastric cancer in a meta-analysis. Gastroenterology 2011; 141(1): 80-9.

https://doi.org/10.1053/j.gastro.2011.03.057

[132] Krejčová $P$, et al. Antiinflammatory and neurological activity of pyrithione and related sulfur-containing pyridine $\mathrm{N}$-oxides from Persian shallot (Allium stipitatum). J Ethnopharmacol 2014; 154(1): 176-82. https://doi.org/10.1016/j.jep.2014.03.066

[133] Lorigooini Z, et al. Evaluation of Anti-Platelet Aggregation Effect of Some Allium Species. Iran J Pharm Res. 2015; 14(4): 1225-31.

[134] Mahboubi M, Kazempour N. The anti-dermatophyte activity of Allium hirtifolium Boiss aqueous extract. J Mycol Med 2015; 25(1): e10-4.

https://doi.org/10.1016/j.mycmed.2014.10.010

[135] Pourzand A, et al. Associations between Dietary Allium Vegetables and Risk of Breast Cancer: A Hospital-Based Matched Case-Control Study. J Breast Cancer 2016 Sep; 19(3): 292-300

https://doi.org/10.4048/jbc.2016.19.3.292

[136] Pal HC, et al. Fisetin and Its Role in Chronic Diseases. Adv Exp Med Biol. 2016; 928: 213-244. https://doi.org/10.1007/978-3-319-41334-1 10

[137] LaFray, Joyce (1987). Tropic Cooking: The New Cuisine from Florida and the Islands of the Caribbean. Oakland: Ten Speed Press. p. 292

[138] Chive Tankin, by Winston J. Craig, Ph. D

[139] Chives from "Sally's place", accessed on May 31, 2009

[140] Allium ampeloprasum, World Check List of Selected Plant Families, Royal Botanic Gardens, Kew. retrieved 2013-02-01. 
[141] Librarie Larousse, ed. (1984). Larousse Gastronomique: The World's Greatest Cooking Encyclopedia. The Hamlyn Publishing Group Limited.
[142] Mehdi M, et al. The effect of Persian shallot (Allium hirtifolium Boiss.) extract on blood sugar and serum levels of some hormones in diabetic rats. Pak J Pharm Sci 2013; 26(2): 397402. 